Article

\title{
Determination of Flavonoid and Proanthocyanidin Profile of Hungarian Sour Cherry
}

\author{
Andrea Nemes ${ }^{1}$ [D, Erzsébet Szőlloosi ${ }^{1}$, László Stündl ${ }^{1}$, Attila Biró ${ }^{1}$, Judit Rita Homoki ${ }^{1}$, \\ Mária Magdolna Szarvas ${ }^{1}$, Péter Balogh ${ }^{2} \mathbb{D}$, Zoltán Cziáky ${ }^{3} \mathbb{D}$ and Judit Remenyik ${ }^{1, * \mathbb{D}}$ \\ 1 Institute of Food Technology, University of Debrecen, H-4032 Debrecen, Hungary; \\ nemes.andrea@agr.unideb.hu (A.N.); szzsoka83@gmail.com (E.S.); stundl@agr.unideb.hu (L.S.); \\ attila.biro88@gmail.com (A.B.); homoki.judit@agr.unideb.hu (J.R.H.); \\ sebestyen.magdolna@agr.unideb.hu (M.M.S.) \\ 2 Faculty of Economics and Business, Institute of Sectoral Economics and Methodology, Department of \\ Research Methodology and Statistics, H-4032 Debrecen, Hungary; balogh.peter@econ.unideb.hu \\ 3 Agricultural and Molecular Research and Service Institute, University of Nyíregyháza, H-4400 Nyíregyháza, \\ Hungary; cziaky.zoltan@nye.hu \\ * Correspondence: remenyik@agr.unideb.hu
}

Received: 7 November 2018; Accepted: 7 December 2018; Published: 11 December 2018

\begin{abstract}
Hungarian sour cherries (SC) are excellent source of anthocyanin (concentrations (100-300 mg in $100 \mathrm{~g}$ fresh fruit) and melatonin $(0.15 \mathrm{mg}$ in $100 \mathrm{~g}$ fresh fruit), but other flavonoid derivatives also can be isolated by aqueous alcoholic extraction. We have developed a new process for extracting non-extractable procyanidines bound to the membrane, proteins, and fibers. These compounds were seperated with UHPLC-MS methods, and the structure of individual components were identified on the basis of their mass fragmentation spectra. The antioxidant capacity of soluble and non-soluble antioxidants were measured with ferric reducing antioxidant power (FRAP), 1,1-diphenyl-2-picrylhydrazyl radical scavenging activity (DPPH), trolox equivalent antioxidant capacity (TEAC) assays, and compared to the new measurement methods of water-soluble antioxidant capacity (ACW), lipid-soluble antioxidant capacity (ACL). Furthermore, total phenolic content (TPC) and total procyanidin content (PAC) were determinated. As a result of our investigation, we found that the solvent combination, where in the first step is water-ethanol (1:1), then $100 \%$ ethanol were suitable for the extraction of the extractable antioxidants. However, the chemiluminescence method that is based on the elimination of the superoxide radical is more accurate than other colorimetric methods which measure antioxidant capacity.
\end{abstract}

Keywords: sour cherry; anthocyanins; extractable polyphenols; non-extractable polyphenols

\section{Introduction}

Sour cherry (Prunus cerasus L.) belongs to the family of Rosaceae, subfamily Prunoideae, to the genus Prunus, subgenus Cerasus. This is the hybrid that is produced by crosses between sweet cherry (Prunus avium (L.) L.) and European dwarf cherry (Prunus fruticosa) [1]. According to the FAOSTAT, world production of sour cherries in 2016 was 1,378,216 tons. The largest producers of cherries are Russia, Poland, Turkey, and the USA. Hungary is only the eighth, with nearly 70 thousand tons. Furthermore, the Hungarian cultivation of sour cherry has several centuries of history. Because of the geographic and climatic conditions of Hungary and the long breeding work, the Hungarian cultivar assortment and their varieties wiht outstanding nutritional parameters were developed, that are unique in the world. The popularity of the Hungarian varieties is shown by the fact that a Hungarian cultivar 'Ujfehértói fürtös' was introduced into the United States in 1984 (in Michigan, 
Utah, and Wisconsin), that is marketed under the name Balaton and is regarded as a super food [2]. In recent years, clinical trials have shown the positive physiological effects of various components that accumulate in the cherry. Different classes of flavonoids have been shown to increase the expression of the gene encoding the $\gamma$-glutamylcysteine synthetase catalytic subunit, a protein reported to be the rate-limiting step in GSH synthesis [3,4]. Cy3G has cytoprotective effects, so it protects cells such as aortic endothelial cells (EC) by reducing hydrogen peroxide $\left(\mathrm{H}_{2} \mathrm{O}_{2}\right)$-induced oxidative stress in vitro and in vivo [5-7]. Youdim et al. (2000) presented for the first time that vascular endothelial cells can incorporate anthocyanins (mainly cyanidin-3-glucoside) into the membrane and cytosol, and the incorporation of anthocyanins by the EC significantly enhanced their resistance to the damaging effects of reactive oxygen species (ROS) [8].

Moreover, flavonoids have anti-oxidative, anti-inflammatory, anti-mutagenic, and anti-carcinogenic properties coupled with their capacity to modulate key cellular enzyme function. Lipoxygenase, xanthine oxidase, and NADPH oxidase enzymes in EC are activated during inflammatory processes. The activity of the NADPH oxidase enzyme can cause endothelial dysfunction in two ways. The activity of the NADPH oxidase enzyme produces oxygen-containing free radicals. The first is that the resulting superoxide anion $(\mathrm{O} 2 \bullet-)$ directly affects the function of the endothelial nitric oxide synthase (eNOS) enzymes by utilizing the cofactor needed for NO synthesis. It follows that the functioning of the eNOS enzyme is disturbed. The second is that $\mathrm{O} 2 \bullet-$ reacts with $\mathrm{NO}$ and connects to peroxinite. Peroxynitrite damages membrane proteins therefore it causes the disruption of mitochondrial electron transport chain [9].

Anthocyanins and some flavone and flavan-3-ol compounds may contribute to the prevention of hypertension [10]. Furthermore, it was demonstrated that the dietary anthocyanin Cy3G acts as a natural activator of eNOS in EC [11]. It has also been known that many extracellular agents (free fatty acids, $\mathrm{H} 2 \mathrm{O} 2$, TNF- $\alpha$ ) contribute to insulin resistance [12].

Furthermore, Guo et al. (2008) investigated the effect of $\mathrm{Cy} 3 \mathrm{G}$ on $\mathrm{H}_{2} \mathrm{O}_{2}$ - and TNF- $\alpha$-induced insulin resistance on the 3T3-L1 adipocyte cell culture. Based on their measurements, it has been demonstrated that Cy3G protects adipocytes by inhibiting the kinase activity of the c-Jun NH2 terminal kinases, so the phosphorylation of the insulin receptor protein (IRS1) occurs via tyrosine [13].

The most significant antioxidant compounds in SC are phenol carboxylic acids (hydroxycinnamic acid, chlorogenic acid, neochlorogenic acid, p-coumaroylquinic acid) [14,15], flavanols (catechin, epicatechin, epigallocatechin, gallocatechin), and derivatives [16,17]. The accumulation of melatonin is also significant $[18,19]$. Polyphenol content in sour cherries and its health effect have been widely studied, for the extractable polyphenols only. Antioxidant capacity is usually measured in food extracts with different combination of organic solvents (e.g., methanol, ethanol, acetone) and water, but these usually do not result complete extraction of antioxidant compounds. This is mainly problem in the case of phenolics compounds, because these compounds are extracted by organic solvents, which probably leaves behind significant other phenolics existing in bound form. Usually, just the amount of extractable fractions were analyzed, the non-extractable compounds (in the solid residue) were ignored and associated with cell wall matrix. Nevertheless, unextractable phenolics from plant foods and their role in health benefits have become increasingly important [14-16].

These non-extractable phenolic compounds are considered to contribute more beneficial effects (gastrointestinal health, cancer, cardiovascular disease) because after gastrointestinal digestion they remain undegraded, and are absorbed into blood plasma after being released by intestinal microflora fermentation $[17,18]$.

Phenolics can be classified as soluble and insoluble-bound form. Thus, the polyphenols that can be extracted from foods with aqueous-organic solvent, called extractable polyphenols (EPP). However, a significant fraction of polyphenols remains in the residue after the extraction; the so-called non-extractable polyphenols (NEPP) [19].

The solid residue contains macromolecules (e.g., high-molecular-weight proanthocyanidins) and single phenolic compounds (e.g., phenolic acids, associated with macromolecules) mainly 
polysaccharide constituents of dietary fibre and protein. NEPP are generally not included in polyphenol analysis, however, the NEPP content may be much higher than the EPP fraction. With regards to their chemical nature, NEPP mainly include polyphenols such as proanthocyanidins, other flavonoids, phenolic acids, and hydrolysable tannins. Accordingly, the NEPP usually were divided into two groups, hydrolysable tannins and non-extractable proanthocyanidins (NEPA) $[18,20]$.

Acid and alkaline hydrolysis are the most common chemical methods used to extract the NEPP and recently, many other new methods such as enzymatic hydrolysis has been employed for better release of NEPP from cell wall matrices [14,21-23].

Plants contain various chemical compounds and the antioxidant effectiveness is determined by many factors (the heterogeneity and heterophasic nature of the system, the type of lipid substrate, including its physicochemical state and degree of unsaturation, the types of initiators (notably transition metals), other components, and their possible interaction).

Because of these, for assessment of antioxidant potential of endogenous compounds, single assay methods are not sufficient.

Several in vitro methods exist to measure the total antioxidant capacity. The different antioxidant assays differ in terms of assay principle and experimental conditions. Depending on what kind of reaction is involved, these assays can be classified into two groups: assays based on hydrogen atom transfer (HAT) reactions and assays based on electron transfer (ET) [24].

The most widely used procedures are FRAP (ferric reducing antioxidant power), ABTS (2,2'-Azino-bis(3-ethylbenzothiazoline-6-sulfonic acid)) or TEAC (trolox equivalent antioxidant capacity), DPPH (2,2-diphenyl-1-picrylhydrazyl), and oxygen radical absorbance capacity (ORAC). The FRAP, TEAC, and DPPH methods belong to ET methods. Unfortunately, however, they have some disadvanteges and limitations. The main disadvantage of FRAP method is that the measured reducing capacity does not necessarily reflect antioxidant activity. Since the method does not include an oxidisable substrate, no information is provided on the protective properties of antioxidants [25]. DPPH assay is limited because DPPH radicals interact with other radicals (alkyl), and the time response curve to reach the steady state is not linear with different ratios of antioxidant/DPPH [26,27]. The TEAC assay also has several limitations. The ability of an antioxidant to scavenge the artificial ABTS radical may not reflect the antioxidant activity due to other mechanisms effective in complex food lipids or physiologically relevant substrates, including metal chelation and effects of antioxidant partitioning among phases of different polarities [25]. The biological and physiological functions of antioxidants are wide-ranging. The identification and quantitative determination of antioxidants, characterization of antioxidant capacity, and the evaluation of interactions between different food matrices can only be done by examining the entire antioxidant system. In order for it to be compare or examine foods with the same or different matrices, an extraction process have to develop that can efficiently obtaining the active compounds, where the componunds retain their chemical composition. Since it is important to identificate the antioxidant compounds, and to determine the antioxidant capacity of the components as accurately as possible. The choice of the right method is also a goal because oxidative stress is well known and studied, but there is antioxidative stress too.

In our opinion, PLC technique (HAT method) can be the best choice to determine the antioxidant capacity, since this method is based on the photo-induced autooxidation inhibition of luminol by antioxidants, mediated from the radical $\mathrm{O}_{2}{ }^{\bullet-}$, which can be found in human body, and is suitable to measure the radical scavenging properties of single antioxidants as well as more complex systems in the nanomolar range.

This study aims at investigating the differences between extraction processes. The first was commonly used combination of methanol, acetone, and water by Saura-Calixto and Goñi [28], and the second was an ethanol extraction that is used by the food and pharmaceutical industry too. During the experiment, not only were the extractable fractions analyzed, but also non-extractable compounds in the solid residue. 


\section{Results and Discussion}

\subsection{Extractable Antioxidant Compounds of Sour Cherry}

Extracts $(1 / \mathrm{A}+1 / \mathrm{B}$ and $2 / \mathrm{A}+2 / \mathrm{B})$, were obtained by the two extraction methods, and analyzed with UHPLC-MS (Table 1). It can be seen that the solution combination 1 and 2 also extracted flavonoids and phenolic components. Among the flavonoids, anthocyanin-glucosides [29] and flavanol-O-glycosides [30] occur in large quantitiesin the sour cherry. The combination of solvent 1 has proved to be more effective mainly in the extraction of procyanidin $\mathrm{C}$ isomer. 
Table 1. Polyphenolic compounds identified by LC-MS in Prunus cerasus L. extracts.

\begin{tabular}{|c|c|c|c|c|c|c|c|c|c|}
\hline \multirow[b]{2}{*}{ No } & \multirow[b]{2}{*}{$\begin{array}{c}\text { RT } \\
{[\mathrm{min}]}\end{array}$} & \multirow[b]{2}{*}{ Compound } & \multirow[b]{2}{*}{$\begin{array}{l}\text { Chemical } \\
\text { Formula }\end{array}$} & \multicolumn{3}{|c|}{ Exact Mass $(\mathrm{m} / \mathrm{z})$} & \multirow[b]{2}{*}{$\Delta \mathrm{ppm}$} & \multirow[b]{2}{*}{ Fragment Ions (relative abundance, \%) } & \multirow[b]{2}{*}{ Reference $^{1}$} \\
\hline & & & & $\begin{array}{c}\text { Measured } \\
{[\mathrm{M}+\mathrm{H}]^{+}}\end{array}$ & $\begin{array}{l}\text { Measured } \\
{\left[\mathrm{M}-\mathrm{H}^{-}\right.}\end{array}$ & Calculated & & & \\
\hline $1^{4}$ & 10.37 & Neochlorogenic acid & $\mathrm{C} 16 \mathrm{H} 18 \mathrm{O} 9$ & 355.10251 & & 355.10291 & -1.13 & 163.0391 (100); 145.0286 (11); 135.0443 (13) & [31] \\
\hline $2^{4}$ & 12.83 & Coumaroylquinic acid isomer ${ }^{1}$ & $\mathrm{C} 16 \mathrm{H} 18 \mathrm{O} 8$ & & 337.09293 & 337.09235 & 1.72 & 191.0553 (52); 163.0388 (100); 119.0487 (48) & [32] \\
\hline $3^{4}$ & 12.84 & Procyanidin B isomer $^{1}$ & $\mathrm{C} 30 \mathrm{H} 26 \mathrm{O} 12$ & & 577.13531 & 577.13460 & 1.23 & 407.0771 (58); 289.0721 (60); 125.0229 (100) & {$[31,33]$} \\
\hline $4^{4}$ & 13.45 & Coumaroylquinic acid isomer $^{2}$ & $\mathrm{C} 16 \mathrm{H} 18 \mathrm{O} 8$ & & 337.09317 & 337.09235 & 2.43 & 191.0555 (10); 163.0388 (100); 119.0487 (44) & [32] \\
\hline $5^{3}$ & 13.92 & Procyanidin C isomer 1 & $\mathrm{C} 45 \mathrm{H} 38 \mathrm{O} 18$ & & 865.19922 & 865.19799 & 1.42 & 407.0771 (23); 289.0729 (30); 125.0229 (100) & [34] \\
\hline $6^{4}$ & 14.12 & Catechin $^{2}$ & $\mathrm{C} 15 \mathrm{H} 14 \mathrm{O} 6$ & & 289.07196 & 289.07121 & 2.60 & 245.0819 (34); 151.0025 (63); 109.0280 (100) & {$[31,33]$} \\
\hline $7^{3}$ & 14.77 & Procyanidin $\mathrm{C}$ isomer ${ }^{2}$ & $\mathrm{C} 45 \mathrm{H} 38 \mathrm{O} 18$ & & 865.19910 & 865.19799 & 1.28 & 407.0774 (25); 289.0722 (26); 125.0230 (100) & [34] \\
\hline $8^{4}$ & 14.94 & Chlorogenic acid $^{2}$ & $\mathrm{C} 16 \mathrm{H} 18 \mathrm{O} 9$ & 355.10211 & & 355.10291 & -2.25 & 163.0390 (100); 145.0286 (11); 135.0443 (12) & {$[31,33]$} \\
\hline $9^{4}$ & 15.21 & Feruloylquinic acid isomer ${ }^{1}$ & C17H20O9 & & 367.10304 & 367.10291 & 0.35 & 193.0498 (100); 173.0445 (7); 134.0360 (65) & \\
\hline $10^{4}$ & 15.77 & Procyanidin B isomer $^{2}$ & С $30 \mathrm{H} 26 \mathrm{O} 12$ & & 577.13519 & 577.13460 & 1.02 & 407.0768 (62); 289.0719 (64); 125.0230 (100) & {$[31,33]$} \\
\hline $11^{3}$ & 16.24 & Chryptochlorogenic acid & $\mathrm{C} 16 \mathrm{H} 18 \mathrm{O} 9$ & 355.10223 & & 355.10291 & -1.92 & 163.0390 (100); 145.0285 (12); 135.0443 (12) & \\
\hline $12^{4}$ & 16.32 & Coumaroylquinic acid isomer ${ }^{3}$ & C16H18O8 & & 337.09201 & 337.09235 & -1.01 & 191.0554 (16); 173.0444 (100); 163.0388 (19) & [32] \\
\hline $13^{4}$ & 16.42 & Feruloylquinic acid isomer $^{2}$ & C17H20O9 & & 367.10301 & 367.10291 & 0.27 & 193.0497 (100); 173.0444 (85); 134.0362 (62) & \\
\hline $14^{3}$ & 17.23 & Cyanidin-3-O-sophoroside & $\mathrm{C} 27 \mathrm{H} 30 \mathrm{O} 16$ & 611.16071 & & 611.16122 & -0.83 & 287.0552 (100); 213.0545 (4); 137.0226 (3) & [35] \\
\hline $15^{3}$ & 17.41 & Procyanidin $\mathrm{C}$ isomer ${ }^{3}$ & $\mathrm{C} 45 \mathrm{H} 38 \mathrm{O} 18$ & & 865.19835 & 865.19799 & 0.42 & 407.0762 (23); 289.0714 (27); 125.0230 (100) & [34] \\
\hline $16^{4}$ & 17.60 & Cyanidin-3-O-glucoside $^{2}$ & $\mathrm{C} 21 \mathrm{H} 20 \mathrm{O} 11$ & 449.10773 & & 449.10839 & -1.47 & 287.0552 (100); 213.0548 (3); 137.0229 (5) & [35] \\
\hline $17^{3}$ & 17.68 & Epicatechin $^{2}$ & $\mathrm{C} 15 \mathrm{H} 14 \mathrm{O} 6$ & & 289.07175 & 289.07121 & 1.87 & 245.0818 (78); 151.0382 (31); 109.0281 (100) & {$[31,33]$} \\
\hline $18^{4}$ & 17.81 & $\begin{array}{l}\text { Cyanidin-3-O-( }{ }^{\mathrm{G}} \text {-glucosyl)- } \\
\text { rutinoside }\end{array}$ & $\mathrm{C} 33 \mathrm{H} 40 \mathrm{O} 20$ & 757.21814 & & 757.21912 & -1.29 & 611.1639 (4); 287.0552 (100); 213.0547 (2) & [35] \\
\hline $19^{4}$ & 18.20 & Coumaroylquinic acid isomer ${ }^{4}$ & $\mathrm{C} 16 \mathrm{H} 18 \mathrm{O} 8$ & & 337.09311 & 337.09235 & 2.26 & 173.0444 (100); 163.0388 (23); 119.0487 (17) & {$[31,33]$} \\
\hline $20^{3}$ & 18.47 & Cyanidin-3-O-rutinoside & C27H30O15 & 595.16626 & & 595.16630 & -0.07 & 449.1094 (4); 287.0552 (100); 213.0551 (2) & [35] \\
\hline $21^{4}$ & 18.54 & $\begin{array}{l}\text { Cyanidin-3-O- }\left(2^{\mathrm{G}}-\right. \\
\text { xylosyl)-rutinoside }\end{array}$ & С $32 \mathrm{H} 38 \mathrm{O} 19$ & 727.20795 & & 727.20855 & -0.83 & 581.1515 (3); 287.0553 (100); 213.0545 (2) & [35] \\
\hline $22^{4}$ & 18.80 & $\begin{array}{l}\text { Pelargonidin-3-O- }\left(2^{\mathrm{G}_{-}}\right. \\
\text {glucosyl)rutinoside }\end{array}$ & C33H40O19 & 741.22491 & & 741.22420 & 0.96 & $271.0602(100)$ & [35] \\
\hline $23^{3}$ & 19.41 & Cinchonain I isomer $^{1}$ & $\mathrm{C} 24 \mathrm{H} 20 \mathrm{O} 9$ & & 451.10318 & 451.10291 & 0.60 & 341.0666 (100); 217.0137 (33) & \\
\hline $24^{3}$ & 19.45 & Pelargonidin-3-O-rutinoside & $\mathrm{C} 27 \mathrm{H} 30 \mathrm{O} 14$ & 579.17096 & & 579.17138 & -0.73 & 433.1135 (4); 271.0603 (100); & [35] \\
\hline
\end{tabular}


Table 1. Cont

\begin{tabular}{|c|c|c|c|c|c|c|c|c|c|}
\hline \multirow[b]{2}{*}{ No } & \multirow[b]{2}{*}{$\begin{array}{c}\text { RT } \\
{[\text { min] }}\end{array}$} & \multirow[b]{2}{*}{ Compound } & \multirow[b]{2}{*}{$\begin{array}{l}\text { Chemical } \\
\text { Formula }\end{array}$} & \multicolumn{3}{|c|}{ Exact Mass $(m / z)$} & \multirow[b]{2}{*}{$\Delta \mathrm{ppm}$} & \multirow[b]{2}{*}{ Fragment Ions (relative abundance, \%) } & \multirow[b]{2}{*}{ Reference $^{1}$} \\
\hline & & & & $\begin{array}{l}\text { Measured } \\
{[\mathrm{M}+\mathrm{H}]^{+}}\end{array}$ & $\begin{array}{l}\text { Measured } \\
{\left[\mathbf{M}-\mathbf{H}^{-}\right.}\end{array}$ & Calculated & & & \\
\hline $25^{4}$ & 20.05 & Peonidin-3-O-rutinoside & $\mathrm{C} 28 \mathrm{H} 32 \mathrm{O} 15$ & 609.18152 & & 609.18195 & -0.71 & 463.1237 (4); 301.0708 (100); 286.0474 (14) & [35] \\
\hline $26^{4}$ & 20.35 & Cyanidin-O-pentoside & C20H18O10 & 419.09750 & & 419.09783 & -0.79 & $287.0554(100)$ & \\
\hline $27^{3}$ & 20.36 & Quercetin-O-(hexosyl)rutinoside & $\mathrm{C} 33 \mathrm{H} 40 \mathrm{O} 21$ & & 771.19940 & 771.19839 & 1.31 & 300.0276 (100); $271.0248(40) ; 255.0298$ (19) & \\
\hline $28^{4}$ & 20.76 & $\begin{array}{l}\text { Quercetin-O-(hexosyl)hexoside } \\
\text { isomer }^{1}\end{array}$ & С27H30O17 & & 625.14056 & 625.14048 & 0.13 & 300.0276 (100); 271.0251 (37); 255.0305 (20) & \\
\hline $29^{3}$ & 20.96 & Quercetin-di-O-hexoside & C27H30O17 & & 625.14111 & 625.14048 & 1.01 & 463.0888 (48); 301.0356 (70); 300.0277 (100) & \\
\hline $30^{4}$ & 21.01 & Procyanidin B isomer ${ }^{3}$ & $\mathrm{C} 30 \mathrm{H} 26 \mathrm{O} 12$ & & 577.13605 & 577.13460 & 2.51 & 407.0768 (31); 289.0724 (53); 125.0229 (100) & {$[31,33]$} \\
\hline $31^{3}$ & 21.09 & Quercetin-O-rutinoside-O-glucoside & $\mathrm{C} 33 \mathrm{H} 40 \mathrm{O} 21$ & & 771,19904 & 771.19839 & 0.84 & 609.1465 (89); 301.0355 (90); 300.0277 (100) & [34] \\
\hline $32^{4}$ & 21.44 & Naringenin chalcone-O-hexoside & $\mathrm{C} 21 \mathrm{H} 22 \mathrm{O} 10$ & & 433.11380 & 433.11348 & 0.74 & 271.0613 (100); 151.0024 (59); 119.0488 (22) & \\
\hline $33^{3}$ & 21.81 & Cinchonain I isomer $^{2}$ & $\mathrm{C} 24 \mathrm{H} 20 \mathrm{O} 9$ & & 451.10123 & 451.10291 & -3.72 & 341.0667 (100); 217.0135 (36) & \\
\hline $34^{4}$ & 22.27 & $\begin{array}{l}\text { Quercetin-O-(hexosyl)hexoside } \\
\text { isomer }^{2}\end{array}$ & C27H30O17 & & 625.14001 & 625.14048 & -0.75 & 300.0277 (100); 271.0244 (33); 255.0288 (18) & \\
\hline $35^{3}$ & 22.81 & Cinchonain I isomer ${ }^{3}$ & $\mathrm{C} 24 \mathrm{H} 20 \mathrm{O} 9$ & & 451.10248 & 451.10291 & -0.95 & 341.0667 (100); 217.0138 (39) & \\
\hline $36^{4}$ & 22.88 & Di-O-caffeoylquinic acid & $\mathrm{C} 25 \mathrm{H} 24 \mathrm{O} 12$ & & 515.11914 & 515.11896 & 0.35 & 353.0879 (60); 191.0553 (100); 179.0339 (62) & \\
\hline $37^{4}$ & 22.99 & Prunin & $\mathrm{C} 21 \mathrm{H} 22 \mathrm{O} 10$ & & 433.11389 & 433.11348 & 0.95 & 271.0612 (100); 151.0024 (41); 119.0487 (26) & [36] \\
\hline $38^{4}$ & 23.55 & Isoquercitrin $^{2}$ & $\mathrm{C} 21 \mathrm{H} 20 \mathrm{O} 12$ & & 463.08810 & 463.08765 & 0.97 & 301.0354 (43); 300.0276 (100); 271.0249 (37) & {$[31,33]$} \\
\hline $39^{4}$ & 23.63 & Rutin $^{2}$ & C27H30O16 & 611.16071 & & 611.16122 & -0.83 & 465.1029 (3); 303.0500 (100); 85.0289 (16) & {$[31,33]$} \\
\hline $40^{3}$ & 23.74 & Dihydroxy(iso)flavone-C-glucoside & $\mathrm{C} 21 \mathrm{H} 20 \mathrm{O} 9$ & 417.11816 & & 417.11856 & -0.96 & 399.1080 (33); 381.0978 (25); 297.0760 (100) & \\
\hline $41^{3}$ & 25.34 & Astragalin & $\mathrm{C} 21 \mathrm{H} 20 \mathrm{O} 11$ & & 447.09348 & 447.09274 & 1.66 & 285.0406 (66); 284.0328 (100); 255.0297 (86) & \\
\hline $42^{4}$ & 25.47 & Nicotiflorin & C27H30O15 & & 593.15094 & 593.15065 & 0.49 & 285.0406 (100); 284.0328 (73); 255.0298 (42) & \\
\hline $43^{3}$ & 25.51 & Cinchonain I isomer ${ }^{4}$ & C24H20O9 & & 451.10400 & 451.10291 & 1.35 & 341.06747 (100); 217.01355 (48) & \\
\hline $44^{4}$ & 25.83 & Narcissin & $\mathrm{C} 28 \mathrm{H} 32 \mathrm{O} 16$ & & 623.16132 & 623.16122 & 0.16 & 315.0512 (100); 314.0435 (44); 299.0197 (40) & {$[31,33]$} \\
\hline $45^{3}$ & 27.30 & $\begin{array}{l}\text { Quercetin-3-O-(4- } \\
\text { coumaroyl)glucoside }\end{array}$ & С $30 \mathrm{H} 26 \mathrm{O} 14$ & & 609.12531 & 609.12444 & 1.43 & 463.0896 (41); 300.0279 (100); 271.0247 25) & {$[31,33]$} \\
\hline $46^{4}$ & 27.89 & Naringenin $^{2}$ & $\mathrm{C} 15 \mathrm{H} 12 \mathrm{O} 5$ & & 271.06122 & 271.06065 & 2.10 & 177.0182 (17); 151.0024 (100); 119.0488 (80) & {$[31,33]$} \\
\hline
\end{tabular}

${ }^{1}$ Identified compounds in Prunus cerasus L. in the literature. ${ }^{2}$ Confirmed by standard. ${ }^{3}$ Detected only in the ethanol/water extract $(1 / \mathrm{A}+1 / \mathrm{B}) .{ }^{4}$ Detected in both extracts $(1 / \mathrm{A}+1 / \mathrm{B}$ and $2 / \mathrm{a}+2 / \mathrm{B})$. 


\subsection{Main Anthocyanin Compounds of Sour Cherry}

The main anthocyanin components in the 'Újfehértói fürtös' variety (Figure 1.) were the cyanidin-3-O-glucosyl-rutinoside, $(2 \mathrm{mg} / 100 \mathrm{~g})$, cyanidin-3-O-rutinoside, (183 $\mathrm{mg} / 100 \mathrm{~g})$ and cyanidin-3-O-monoglucoside $(4.29 \mathrm{mg} / 100 \mathrm{~g})$.

The antioxidant capacity of these components is determined by $\mathrm{OH}$ groups at positions $\mathrm{C}^{\prime}{ }^{\prime}$ and $\mathrm{C} 4^{\prime}$ on the chalcone.

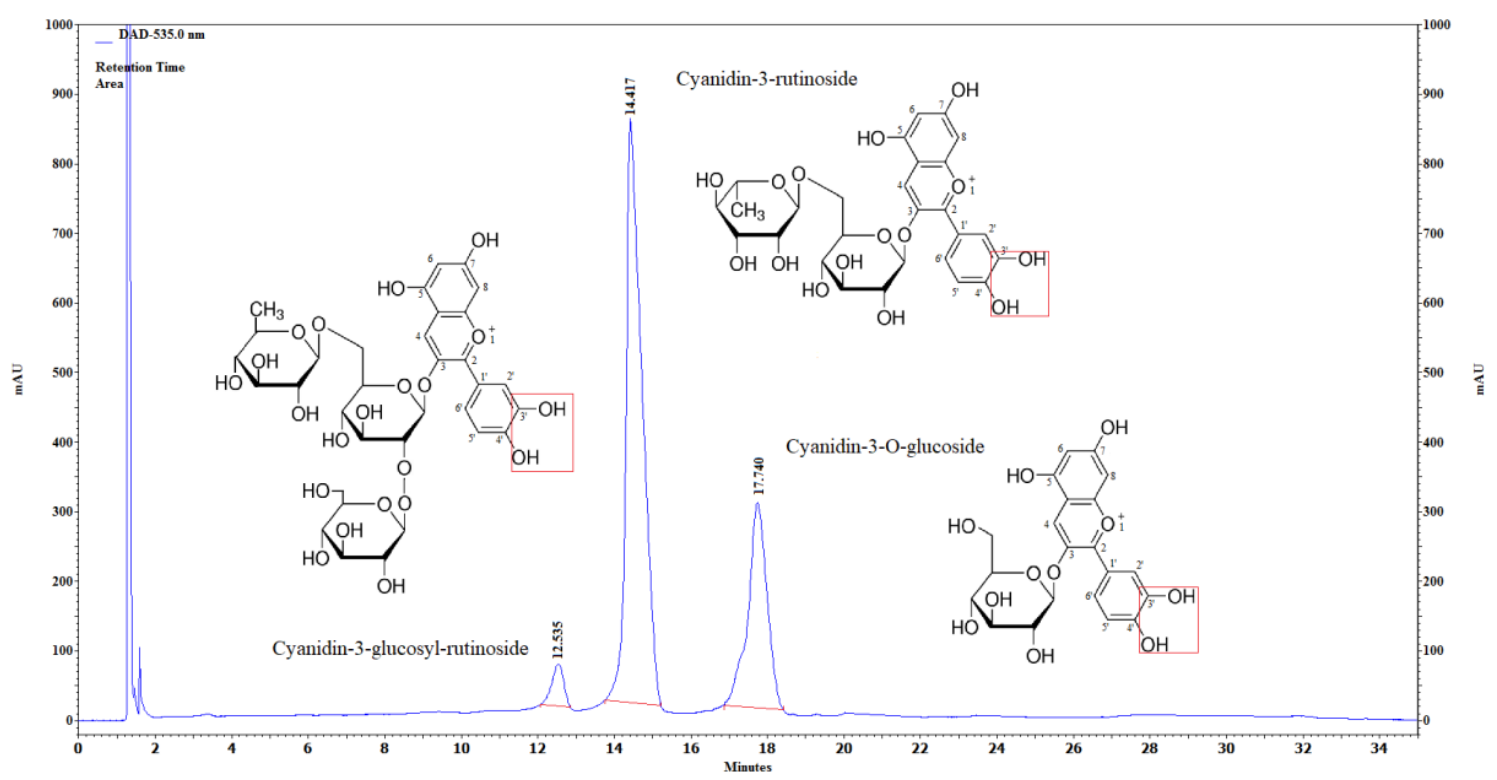

Figure 1. UHPLC chromatogram of sour cherry at $535 \mathrm{~nm}$. Confirmed by standard.

\subsection{Main Flavonoid and Phenolic Compounds of Sour Cherry}

Quercetin, quercetin-3 rutinoside and apigenin (flavonoids) occur in abundant quantities in sour cherry (Figure 2.). These are precursor compounds in the biosynthesis of anthocyanins. There are other phenolic compounds like chlorogenic and caffeic acid in high concentrations in this fruit. The antioxidant activity of these compounds is also high.

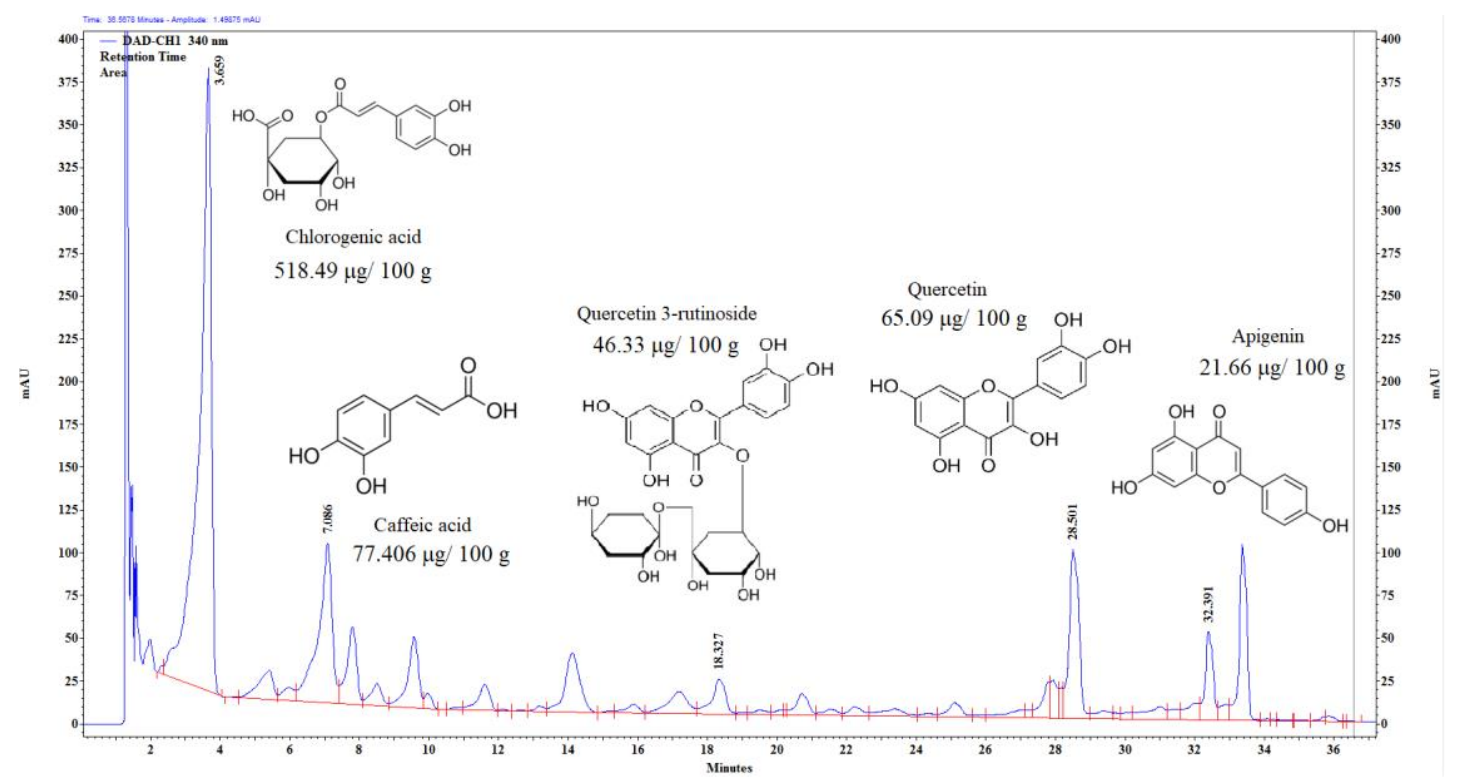

Figure 2. UHPLC chromatogram of sour cherry at $340 \mathrm{~nm}$. Confirmed by standard. 


\subsection{Total Procyanidin Content (PAC) of Sour Cherry and Sour Cherry Residues}

Several studies have been reported that procyanidins have strong protective properties regarding oxidative damage, microbial infection, prevention of colon cancer, and prevention of cardiovascular disease [37-40]. However, the degree of polymerization (DP) of procyanidins may be highly influential and determine these effects [41-43]. In the gastrointestinal tract, procyanidin monomers, dimers, and trimers are absorbed into the blood system to a much larger extent than larger oligomers and polymers $[44,45]$. The DP value of sour cherry procyanidins is lower than 4 , indicating the relatively high levels of better absorbable short-chain procyanidin species [46], so sour cherry is an exceptional source of short-chain procyanidins, and a major food ingredient.

Measurably higher amounts of mono-, di-, and trimer procyanidins were extracted with the solvent combination 1 , since fewer remained in the residue $1 / R$, however, the total amount of procyanidins could be not extracted (Figure 3.).

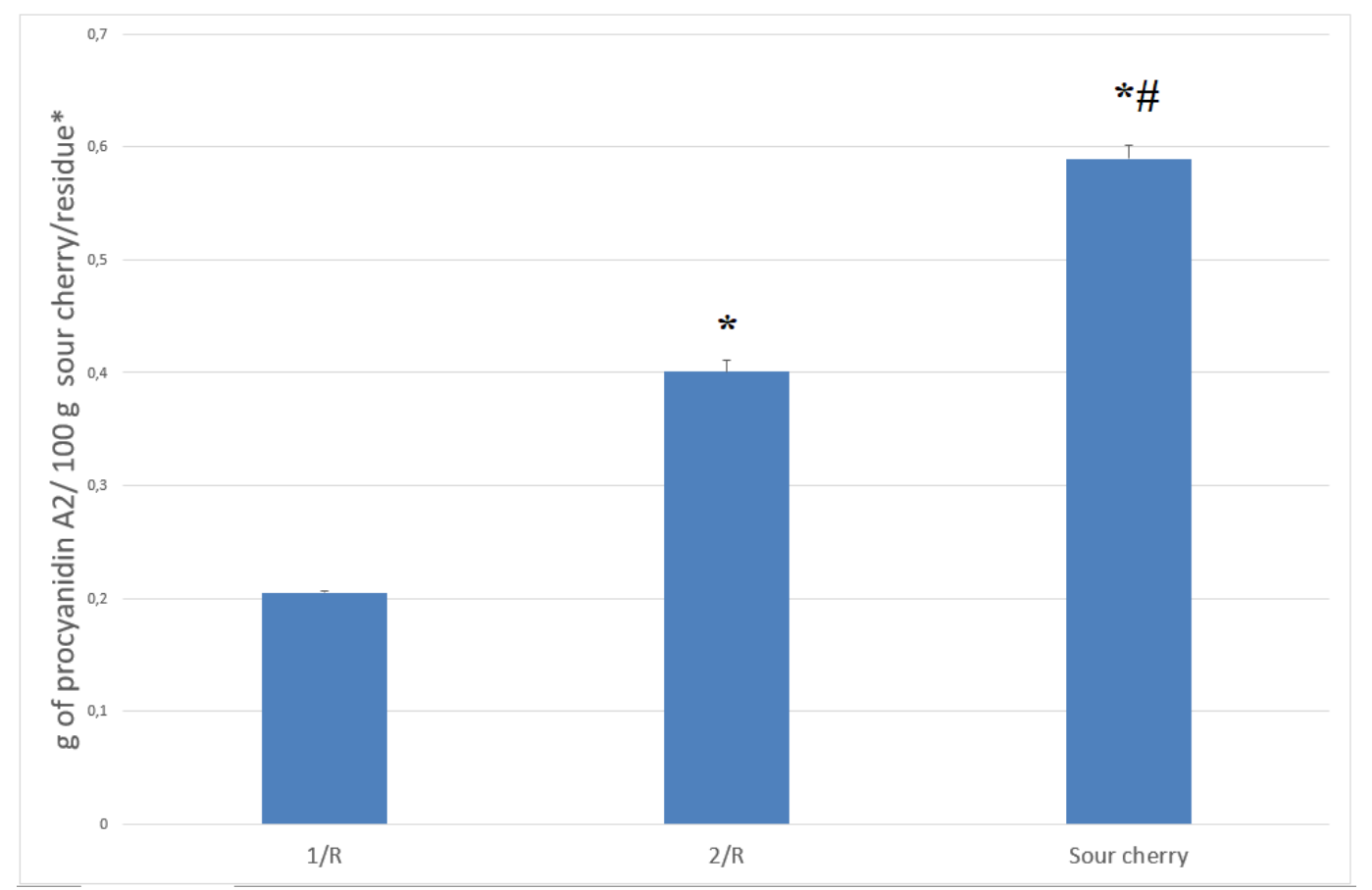

Figure 3. The total procyanidin content of sour cherry and sour cherry residues. ${ }^{*}$ Units for different type of samples: sour cherry sample: $g$ of procyanidin A2/100 $\mathrm{g}$ fresh weight sour cherry; residues: $\mathrm{g}$ of procyanidin A2/100 g dried residue. Abbreviations: 1/R: residue of 'solvent combination 1 '; $2 / \mathrm{R}$ : residue of 'solvent combination 2 ' . ${ }^{*}$ indicates significant difference $(p<0.05)$ from the $1 / \mathrm{R}$. \# indicates significant difference $(p<0.05)$ between the $2 / \mathrm{R}$ and the sour cherry.

\subsection{Identification of Cinconain I}

As you can see in the Table 1, the peaks for Cinchonain I isomers are 19.41, 21.81, 22.81, and $25.51 \mathrm{~min}$. with $[\mathrm{M}-\mathrm{H}]^{-}$ions at $m / z 451.10291$ were identified as distereomers of Cinchonain I on the bases of their exact molecular mass, isotopic pattern, and fragmentation. The characteristic fragment ions are 451.10400, 341.06747, and 217.0155 (Figure 4.). 


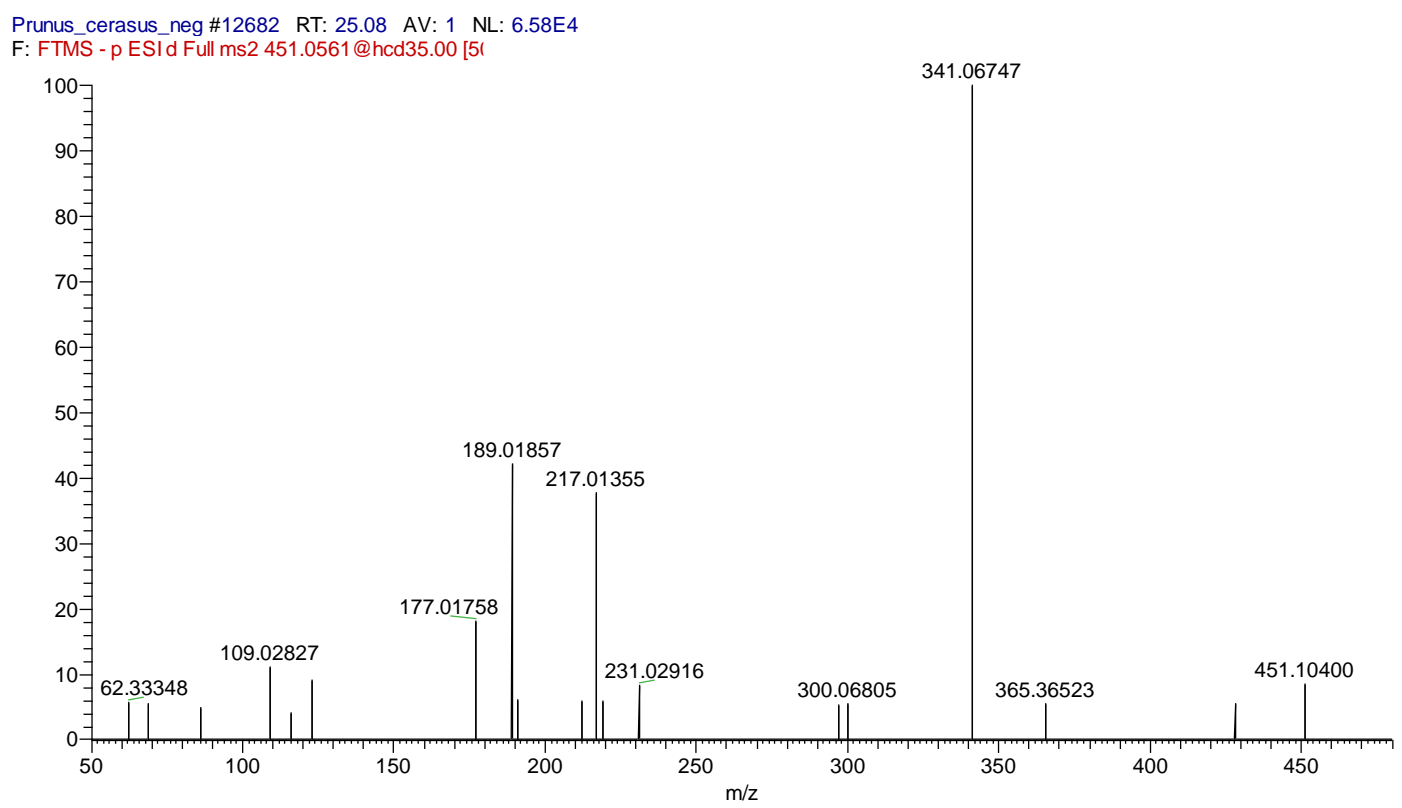

Figure 4. ESI-MS2 spectrum of Cinchonain I diastereoisomer at retention time 25.51.

\subsection{Extractable Antioxidant Capacity of Sour Cherry Extracts}

The antioxidant activites were compared in case of solvent combination 1 and 2, using the well-known measuring methods FRAP, DPPH, TEAC, ACL, ACW, and TPC (Figure 5A.).

Our results show that the amount of antioxidant compounds extracted by these two methods is not significantly different. The aqueous-alcoholic mixture is more advantageous for the processing industry and is sufficient to extract the most important compounds of the sour cherry (anthocyanins, procyanidines, phenolic components, and flavonoids). These compounds slightly soluble in water, but ethanol is a good solvent for them. Because of the polarity of 1/A mixture, it is also suitable for extraction of low molecular weight organic acids, which provides $\mathrm{pH} 3$ in which glycolized anthocyanins maintain their chemical structure (more acid is not required.). All the other antioxidants can be extracted with ethanol (1/B).

UHPLC-MS measurements show (Table 1 ) that combinations of $1 / \mathrm{A}$ or $1 / \mathrm{B}$ and $2 / \mathrm{A}$ or $2 / \mathrm{B}$ are only partially applicable to the extraction of bioactive compounds, because all sour cherry extracts (1/AS, 1/BS, 2/AS, 2/BS) include 'anthocyanin and procyanidins', 'flavonoids', and 'other polyphenols'. The difference is only the amount of extracted compounds, that depends on solubility. It is therefore not surprising that methods based on the measurement of water-soluble polar components can measure a lower antioxidant concentration.

The used assays (except for ACL, ACW) are colorimetric methods based on complexometry, and have many disadvantages. The most significant drawback of the FRAP method is that it is only suitable for measuring water soluble components. In addition, not all antioxidants are able to reduce $\mathrm{Fe}^{3+}$, antioxidants that act by $\mathrm{H}$ atom transfer are not detected [47-49]. During the application of the TEAC method, the problem is that the reaction of ABTS+ $\bullet$ with the antioxidant compounds is strongly time-dependent, so components with 'slow kinetic' do not react with the radical in time [47]. DPPH is mainly used to measure the ability of polyphenols to transfer labile $\mathrm{H}$ atoms to radicals [50].

Obviously, the determination of antioxidant capacity of antioxidant compounds, that are extracted with solvent combination 1 and 2 by chemiluminescence technique seem to be the most appropriate. This method is suitable for selectively determining the concentration of water-soluble and lipid-soluble antioxidants. It can be used for antioxidants that act $\mathrm{H}$ atom transfer and electron transfer, because both groups react with the superoxide anion, which is one of the most important radicals in the living organisms [51,52]. 


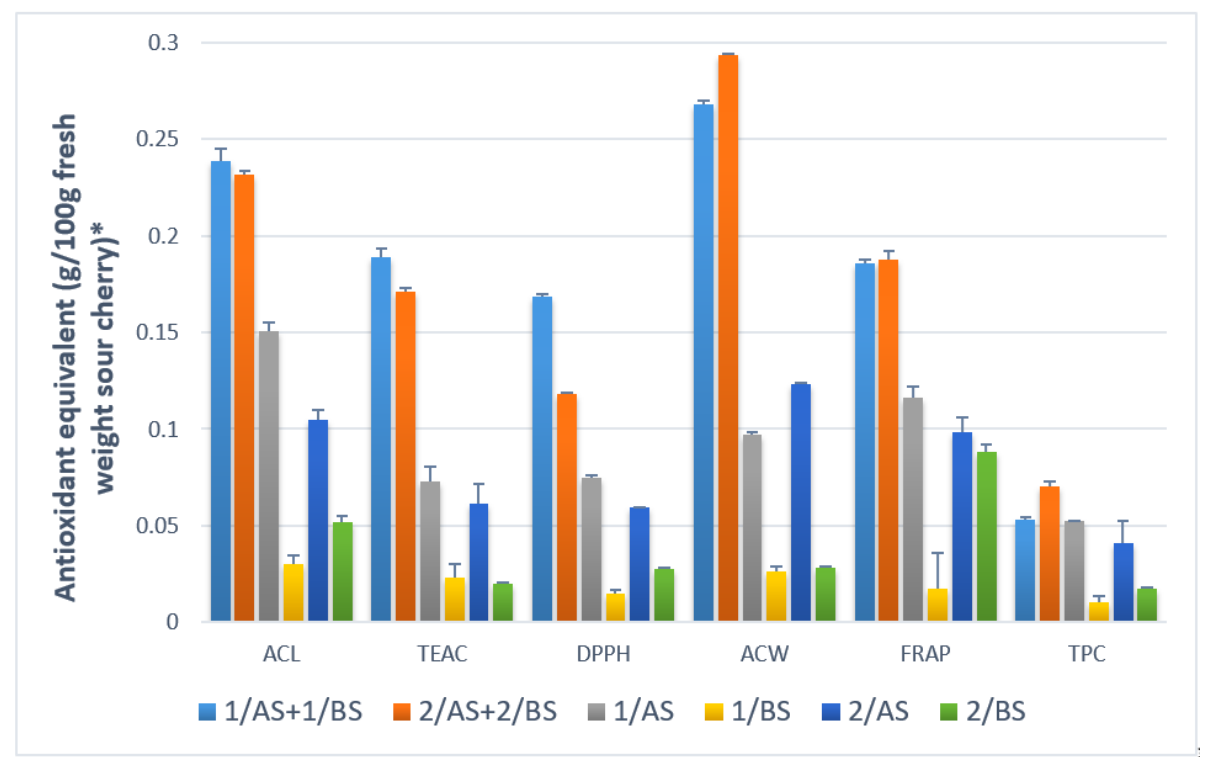

(A)

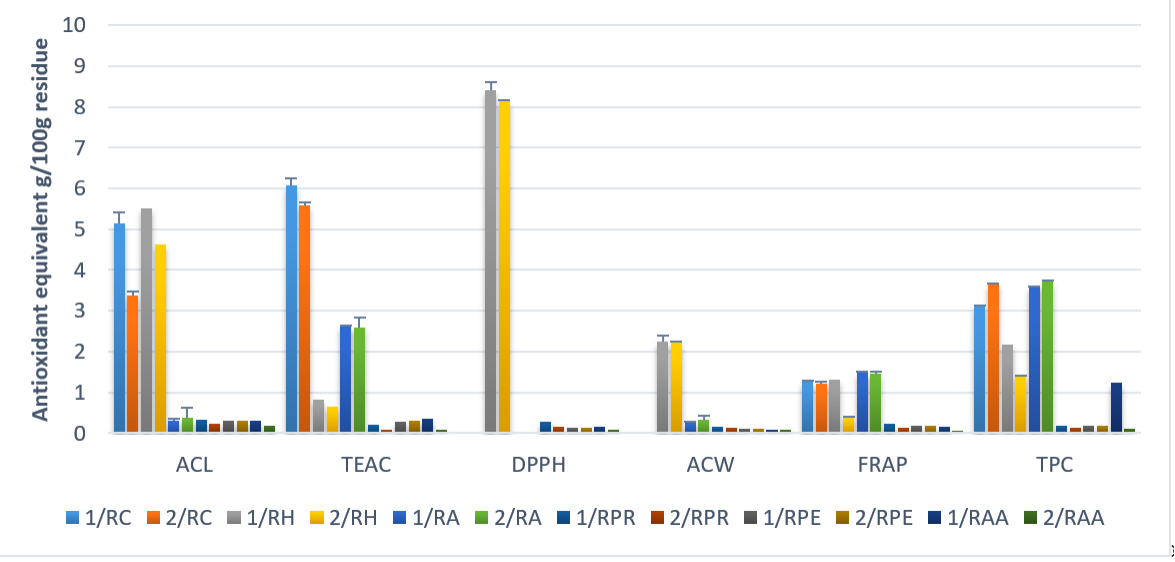

(B)

Figure 5. ESI-MS2 spectrum of procyanidin B. (A) Comparison of the extractable antioxidant capacity of sour cherry-extracts and the totalphenolic content. ${ }^{*}$ Units for different measurement methods: ACL: Trolox equivalent g/100 g; TEAC: Trolox equivalent g/100 g; DPPH: Trolox equivalent g/100 g; ACW: Ascorbic acid g/100 g; FRAP: Ascorbic acid g/100 g; TPC: Gallic acid g/100 g. Abbreviations: 1/AS: evaporated ethanol:water extract; 1/BS: evaporated ethanol extract after ethanol:water extraction; 1 /AS + 1/BS: 1/AS and 1/BS extracts evaporated together; $2 / \mathrm{AS}$ : evaporated acidic methanol:water extract; 2/BS: evaporated acetone:water extract after methanol:water extraction; 2/AS + 2/BS: 2/AS and 2/BS extracts evaporated together. The table form (Supplement 1 ) with the results of the statistical analysis can be found in the Supplemets secyion. (B) Comparison of the non-extractable antioxidant capacity of sour cherry residue extracts and the totalphenolic content. ${ }^{*}$ Units for different measurement methods: ACL: Trolox equivalent g/100 g; TEAC: Trolox equivalent g/100 g; DPPH: Trolox equivalent g/100 g; ACW: Ascorbic acid g/100 g; FRAP: Ascorbic acid g/100 g; TPC: Gallic acid g/100 g. Abbreviations: $1 / \mathrm{R}$ : residue of 'solvent combination 1 '; 1 / RC: supernatant from the 'extraction of hydrolysable tannins' of $1 / \mathrm{R} ; 1 / \mathrm{RH}$ : supernatant from the 'extraction of condensed tannins' of $1 / \mathrm{R} ; 1 / \mathrm{RA}$ : supernatant from the 'alkaline hydrolysis' of $1 / R ; 1 / R P R$ : supernatant from the 'protease hydrolysis' of $1 / R$; $1 /$ RPE: supernatant from the 'pectinase hydrolysis' of $1 / \mathrm{R} ; 1 / \mathrm{RAA}$ : supernatant from the ' $\alpha$-amilase hydrolysis' of $1 / R ; 2 / R$ : residue of 'solvent combination 2 '; $2 / R C$ : supernatant from the 'extraction of hydrolysable tannins' of 2/R; 2/RH: supernatant from the 'extraction of condensed tannins' of 2/R; 2/RA: supernatant from the 'alkaline hydrolysis' of 2/R; 2/RPR: supernatant from the 'protease hydrolysis' of 2/R; 2/RPE: supernatant from the 'pectinase hydrolysis' of 2/R; 2/RAA: supernatant from the ' $\alpha$-amilase hydrolysis' of $2 / R$; The table form (Supplement 2 ) with the results of the statistical analysis can be found in the Supplemets chapter. 


\subsection{Capacity of Non-Extractable Antioxidants of Sour Cherry Extracts}

The enzymatic digestion not resulted significant antioxidant activity (Figure 5B.). The explanation is that sour cherry does not contain large amounts of starch, so the $\alpha$-amylase hydrolisis is not relevant. It does not contain large amounts of protein, so hydrolysis with protease is not important either. The use of pectinase is also more important for apple crops.

Significant amounts of antioxidant fragments were obtained in the case of the alkaline treatment, but mainly acidic hydrolysis. The results obtained using the $\mathrm{HCl}$ butanol extractant are not significantly different. Low molecular weight phenolic derivatives resulting from the degradation of polyphenols may be responsible for the apparently high antioxidant activity.

Proantocianines are considered as non-extractable components but some of them can be recovered with a solvent combination 1 and 2, as can be seen from the Table 1 . However, non-extractable proantocianidines can not be identified in the hydrolysates.

The amount of antioxidants that extracted from the sour cherry and obtained from hydrolysis from the remaining residues were similar in case of the solvent combination (Figure 5A,B). Thus, the acidification $(\mathrm{HCl})$ and the methanol-acetone-water solvent combination that was used by Saura-Calixto and Goñi [28] did not extract significantly higher amounts of antioxidant compounds. Consequently, it is not necessary to use $\mathrm{HCl}$, and the methanol can be replaced by etanol in the first step, furthermore the acetone water combination can be replaced by $100 \%$ ethanol in the second step.

\section{Experimental}

\subsection{Plant Material}

Stoned, frozen sour cherry ('Újfehértói fürtös' variety) was bougth from Mirelite Mirsa Zrt (Albertirsa, Hungary) in 2017. Fruit samples were frozen $\left(-20^{\circ} \mathrm{C}\right)$ and stored in dark.

\subsection{Chemicals and Reagents}

Ethanol, acetic acid, and Folin-Ciocalteu's reagent were purchased from VWR (Randore, PA, USA). Hydrochloric acid and 1-Butanol were obtained from Merck (Damstadt, Germany). Methanol, acetone, sulfuric acid, 2, 4, 6-Tris(2-pyridyl)-s-triazine (TPTZ), 2,2-Diphenyl-1-picrylhydrazyl (DPPH), 2,2'-azino-bis(3-ethylbenzothiazoline-6-sulforic acid) (ABTS), 4-(dimethylamino)cinnamaldehyde (DMAC), iron(III) chloride hexahydrate, sodium acetate trihydrate, potassium persulfate, procyanidin A2, sodium carbonate anhydrous, ascirbic acid, ( \pm )-6-Hydroxy-2,5,7,8-tetramethylchromane-2carboxylic acid (Trolox), gallic acid, sodium hydroxide, antioxidant standards, and the enzymes (protease, $\alpha$-amylase) were purchased from Sigma-Aldrich (St. Louis, MO, USA). Pectinex XXL enzyme was obtained from Novozymes (Bagsværd, Denmark). Dulbecco's phosphate-buffered saline (DPBS) were obtained from iBioTech (Szigetszentmiklós, Hungary). ACL and ACW kits were obtained from Greenlab (Budapest, Hungary). In our experiments, all the reagents were analytical grade. HPLC-grade methanol and formic acid were purchased from Fisher Scientific (Hampton, NH, USA).

\subsection{Extraction of Extractable Antioxidants}

The sour cherry was defrosted and homogenized. Then two different solvents were used to extract antioxidant compounds. Each extraction was performed parallel three times.

\subsubsection{Extraction with the Mixture of Ethanol and Water (Solvent Combination 1)}

$200 \mathrm{~g}$ of sample was extracted with $150 \mathrm{~mL}$ ethanol (96\%) and $150 \mathrm{~mL}$ distilled water for $2 \mathrm{~h}$ (1/A). The samples were centrifuged (Eppendorf Cetrifuge 5810R)) for $15 \mathrm{~min}$ at $4000 \mathrm{rpm}$ and the supernatant was recovered.

$150 \mathrm{~mL}$ ethanol (96\%) was added to the residue, and the mixture was mixed for $2 \mathrm{~h}(1 / \mathrm{B})$. After centrifugation (15 $\mathrm{min}, 4000 \mathrm{rpm}$ ), the supernatant was recovered. 
For the first time, supernatants from $1 / \mathrm{A}$ and $1 / \mathrm{B}$ were evaporated together (1/AS + 1/BS), but in the second case separately (1/AS and 1/BS). Evaporation was performed at $40^{\circ} \mathrm{C}, 10 \mathrm{mbar}$ (Figure 6).

The residue (1/R) was lyophilised (ScanVac CoolSafe 55-4 Pro lyophilizer), homogenized (Gorenje SMK 150 B coffee grinder), and stored in freezer $\left(-20^{\circ} \mathrm{C}\right)$ before use.

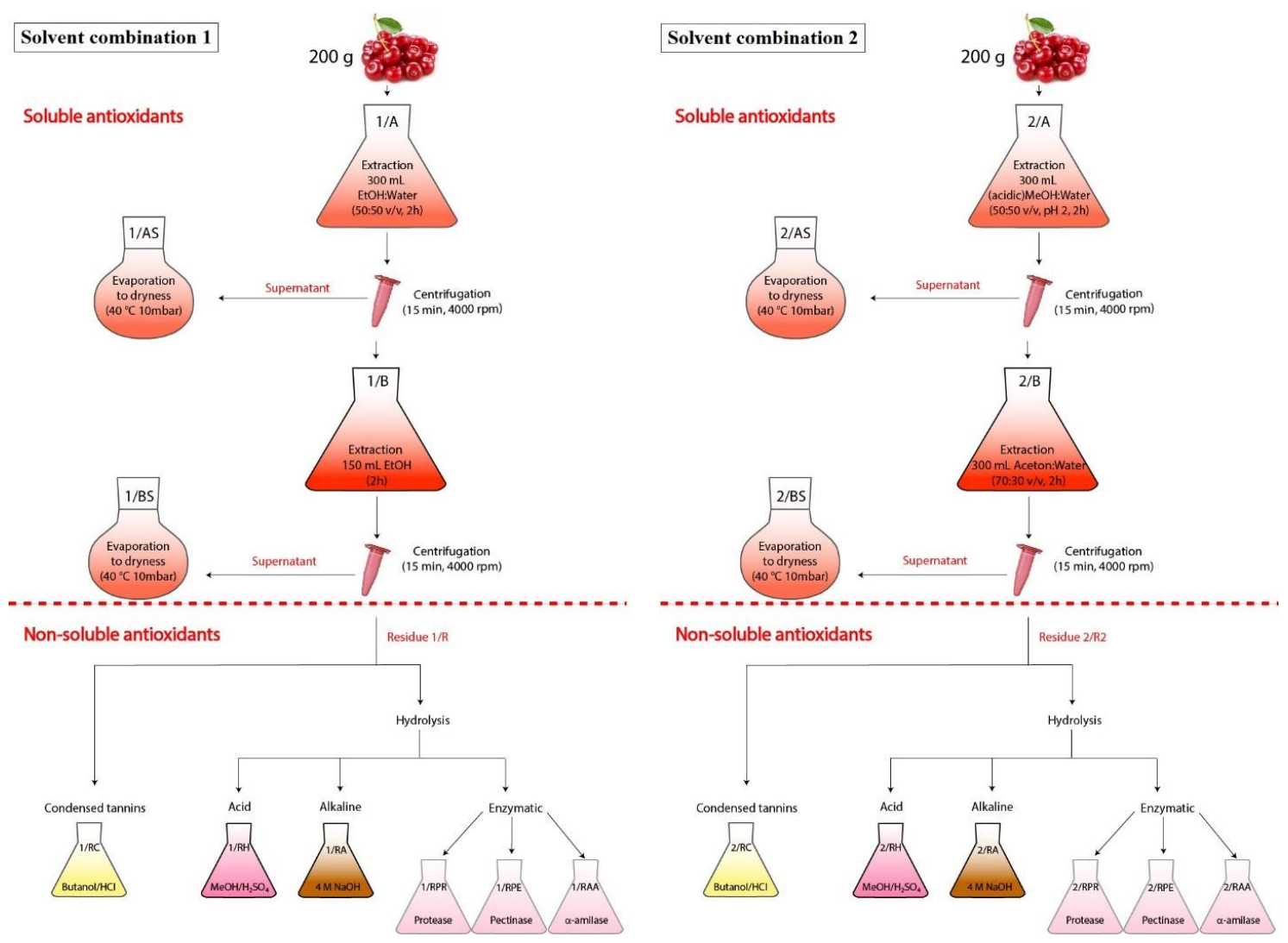

Figure 6. Scheme of the extraction of antioxidants from sour cherry. Abbreviations: 1/AS: evaporated ethanol:water extract; 1/BS: evaporated ethanol extract after ethanol:water extraction; $1 / \mathrm{AS}+1 / \mathrm{BS}$ : 1/AS and 1/BS extracts evaporated together; 2/AS: evaporated acidic methanol:water extract; 2/BS: evaporated acetone:water extract after methanol:water extraction; 2/ AS + 2/BS: 2/ AS and 2/BS extracts evaporated together; $1 / \mathrm{R}$ : residue of 'solvent combination 1 '; $1 / \mathrm{RC}$ : supernatant from the 'extraction of hydrolysable tannins' of $1 / \mathrm{R} ; 1 / \mathrm{RH}$ : supernatant from the 'extraction of condensed tannins' of $1 / R ; 1 / R A$ : supernatant from the 'alkaline hydrolysis' of $1 / R ; 1 / R P R$ : supernatant from the 'protease hydrolysis' of $1 / R ; 1 / R P E$ : supernatant from the 'pectinase hydrolysis' of $1 / R ; 1 / R A A$ : supernatant from the ' $\alpha$-amilase hydrolysis' of $1 / R ; 2 / R$ : residue of 'solvent combination 2 '; $2 / R C$ : supernatant from the 'extraction of hydrolysable tannins' of $2 / \mathrm{R} ; 2 / \mathrm{RH}$ : supernatant from the 'extraction of condensed tannins' of 2/R; 2/RA: supernatant from the 'alkaline hydrolysis' of 2/R; 2/RPR: supernatant from the 'protease hydrolysis' of 2/R; 2/RPE: supernatant from the 'pectinase hydrolysis' of 2/R; 2/RAA: supernatant from the ' $\alpha$-amilase hydrolysis' of $2 / R$.

\subsubsection{Extraction of Extractable Antioxidants According to Saura-Calixtoa and Goñi [28] (Solvent} Combination 2)

$200 \mathrm{~g}$ of sample was extracted with $300 \mathrm{~mL}$ acidic methanol/water/ $\mathrm{HCl}$ (50:50; pH 2) were added (2/A) for $2 \mathrm{~h}$, then centrifuged (15 $\mathrm{min}, 4000 \mathrm{rpm})$ and the supernatant was recovered.

$300 \mathrm{~mL}$ acetone/water (70:30, v/v) was added to the residue, and the mixture was mixed for $2 \mathrm{~h}$ (2/B). After centrifugation (15 $\mathrm{min}, 4000 \mathrm{rpm})$, the supernatant was recovered [28]. 
The extraction was performed twice. For the first time, supernatants from $2 / \mathrm{A}$ and $2 / \mathrm{B}$ were evaporated together (2/AS + 2/BS), but in the second case separately (2/AS and 2/BS). Evaporation was performed at $40^{\circ} \mathrm{C}, 10 \mathrm{mbar}$ (Figure 6).

The residue $(2 / \mathrm{R})$ was lyophilised, homogenized, and stored in freezer $\left(-20^{\circ} \mathrm{C}\right)$ before use.

\subsubsection{Preparation of Extracts from UHPLC}

The purification of anthocyanins, a simple fractionation of sour cherry extracts ( $1 / A+1 / B$ and 2/A + 2/B) was performed using preconditioned Supelclean ENVI-18 SPE tubes [53]. The tubes were conditioned with $5 \mathrm{~mL} \mathrm{MeOH}$ then with $5 \mathrm{~mL} \mathrm{H}_{2} \mathrm{O}$ and finally $1 \mathrm{~mL}$ of fruit sample was applied. The anthocyanins were eluted with methanol:water; 80:20. Solvent was evaporated at $40{ }^{\circ} \mathrm{C}$ with Heidolph Hei-VAP Value rotary evaporator (Schwabach, Germany).

\subsection{Acid Hydrolysis}

\subsubsection{Extraction of Hydrolysable Tannins}

10-10 mg dried sour cherry residue powder from the two extractions were subjected to hydrolysis with $2 \mathrm{~mL}$ methanol and $200 \mu \mathrm{L}$ sulphuric acid for $20 \mathrm{~h}$ at $85^{\circ} \mathrm{C}$. Samples are then centrifuged $(2500 \mathrm{~g}$, $10 \mathrm{~min}$ ) and supernatants recovered. The residues was washed with $2-2 \mathrm{~mL}$ distilled water two times [54]. The supernatant from $1 / \mathrm{R}$ residue is $1 / \mathrm{RH}$, and the extract from $2 / \mathrm{R}$ residue is $2 / \mathrm{RH}$.

\subsubsection{Extraction of Condensed Tannins}

10-10 mg dried sour cherry residue powder from the two extractions were treated with $3 \mathrm{~mL}$ $\mathrm{HCl} /$ butanol (5:95) and $100 \mu \mathrm{L} \mathrm{FeCl}_{3}(2 \mathrm{wt} \%)$ at $100{ }^{\circ} \mathrm{C}$ for $3 \mathrm{~h}$. After centrifugation ( $\left.2500 \mathrm{~g}, 10 \mathrm{~min}\right)$, the supernatant was recovered. The residues were washed with $2-2 \mathrm{~mL} \mathrm{HCl} /$ butanol (5:95) two times. The supernatant from $1 / \mathrm{R}$ residue is $1 / R C$, and the extract from $2 / \mathrm{R}$ residue is $2 / \mathrm{RC}[55,56]$.

\subsection{Alkaline Hydrolysis}

$0.1 \mathrm{~g}$ dried sour cherry residue powder from the two extractions were treated with $5 \mathrm{~mL} \mathrm{NaOH}$ $(4 \mathrm{mM})$ at $25{ }^{\circ} \mathrm{C}$ for $1 \mathrm{~h}$. After centrifugation $(4000 \mathrm{rpm}, 10 \mathrm{~min})$, the supernatant was recovered. The supernatant from $1 / \mathrm{R}$ residue is $1 / \mathrm{RA}$, and the hydrolysate from $2 / \mathrm{R}$ residue is $2 / \mathrm{RA}$ [23].

\subsection{Enzymatic Hydrolysis}

\subsubsection{Enzymatic Hydrolysis with Protease}

$5 \mathrm{~mL}$ DPBS and $10 \mu \mathrm{L}$ tyrosine $(50 \mathrm{mg} / \mathrm{mL} ; 3550$ tyrosine units $/ \mathrm{mL})$ was added to $0.1 \mathrm{~g}$ dried sour cherry residue powder from the two extractions. The samples were incubated at $60^{\circ} \mathrm{C}$ for $1 \mathrm{~h}$. To stop the enzymatic hydrolisis, the hydrolysates were placed in a water bath at $100{ }^{\circ} \mathrm{C}$ for $10 \mathrm{~min}$. After centrifugation ( $5 \mathrm{~min}, 4000 \mathrm{rpm}$ ), the supernatant was recovered. The hydrolysate from $1 / \mathrm{R}$ residue is $1 / R P R$, and the supernatant from $2 / R$ residue is $2 / R P R$.

\subsubsection{Enzymatic Hydrolysis with Pectinase}

$5 \mathrm{~mL}$ DPBS and $10 \mu \mathrm{L}$ pectinase (Pectinex XXL) was added to $0.1 \mathrm{~g}$ dried sour cherry residue powder from the two extractions. The samples were incubated at room temperature for $1 \mathrm{~h}$. To stop the enzymatic hydrolisis, the hydrolysates were placed in a water bath at $100{ }^{\circ} \mathrm{C}$ for $5 \mathrm{~min}$. After centrifugation ( $5 \mathrm{~min}, 4000 \mathrm{rpm}$ ), the supernatant was recovered. The supernatant from $1 / \mathrm{R}$ residue is $1 / \mathrm{RPE}$, and the hydrolysate from $2 / \mathrm{R}$ residue is $2 / \mathrm{RPE}$ [22].

\subsubsection{Enzymatic Hydrolysis with $\alpha$-amilase}

$5 \mathrm{~mL}$ DPBS and $10 \mu \mathrm{L} \alpha$-amilase (3000 Units $/ \mathrm{mL}$ ) was added to $0.1 \mathrm{~g}$ dried sour cherry residue powder from the two extractions. The samples were incubated at $37^{\circ} \mathrm{C}$ for $10 \mathrm{~min}$. To stop the 
enzymatic hydrolisis, the hydrolysates were placed in a water bath at $100{ }^{\circ} \mathrm{C}$ for 20 min. After centrifugation (5 $\mathrm{min}, 4000 \mathrm{rpm}$ ), the supernatant was recovered. The supernatant from $1 / \mathrm{R}$ residue is $1 /$ RAA, and the hydrolysate from $2 / \mathrm{R}$ residue is $2 / \mathrm{RAA}[23]$.

\subsection{Determination of Total Phenolic Content (TPC)}

Total phenolics in all extracts were determined with the Folin-Ciocalteu assay [57] with minor modifications. $10 \mu \mathrm{L}$ of appropriately diluted extracts, standard gallic acid solutions (50, 100, 200, 400, 800 , and $1600 \mu \mathrm{g} / \mathrm{mL}$ ) or water (blank) was mixed with $190 \mu \mathrm{L}$ of distilled water in a well of a 96-well plate; $25 \mu \mathrm{L}$ of Folin-Ciocalteu reagent solution was then added. After $6 \mathrm{~min}, 75 \mu \mathrm{L}$ of $7 \% \mathrm{Na}_{2} \mathrm{CO}_{3}$ was added. The mixture was shaken gently and incubated in the pre-heated chamber $\left(50{ }^{\circ} \mathrm{C}\right)$ for $10 \mathrm{~min}$, and its absorbance was measured at $765 \mathrm{~nm}$, using the microplate reader (SPECTROstar ${ }^{\circledR N a n o}$, BMG Labtech, Ortenberg, Germany). TPC was expressed as milligrams of gallic acid equivalents (mg GAE/100 g fresh weight sour cherry/dried residue). In some cases, the extract was too dilute, so $100 \mu \mathrm{L}$ of sample and $100 \mu \mathrm{L}$ of $\mathrm{H}_{2} \mathrm{O}$ were mixed in a well.

\subsection{Determination of Total Procyanidin Content (PAC)}

Total procyanidin content was measured using the method of Prior et al. [58].

Dried powder of residuals and sour cherry were weighed $(500 \mathrm{mg}$ ) into a $50 \mathrm{~mL}$ conical tube. $20 \mathrm{~mL}$ extraction solution (acetone/deionized water/acetic acid 75:24.5:0.5) was added to the samples. The samples were vortexed for $30 \mathrm{~s}$ followed by sonication for $1 \mathrm{~h}$ at room temperature. After centrifugation (4000 rpm, $10 \mathrm{~min}$ ), the supernatant was collected for analysis.

$70 \mu \mathrm{L}$ of $96 \%$ ethanol for blank; or $70 \mu \mathrm{L}$ of control $\left(100 \mu \mathrm{g} \mathrm{mL} \mathrm{mL}^{-1}\right.$ Procyanidin $\mathrm{A} 2$ in ethanol)/standard/samples were added to $210 \mu \mathrm{L}$ DMAC solution (0.1 wt \% in ethanol) in a well of 96-well plate. The mixture was shaken gently and incubated in the pre-heated chamber $\left(25^{\circ} \mathrm{C}\right)$. The microplate was read for $25 \mathrm{~min}$.

The plate reader protocol was set to read the absorbance $(640 \mathrm{~nm})$ of each well in the plate every min for $30 \mathrm{~min}$. The maximum absorbance readings were used for calculation.

\subsection{Determination of Antioxidant Capacity}

In this experiment, FRAP, DPPH, TEAC, and PCL (Photochemiluminescence assay) methods were used to measure, the antioxidant capacity.

\subsubsection{FRAP}

The ferric reducing antioxidant power assay was performed as previously described by Benzie and Strain [59]. It is based on the reduction of the Fe ${ }^{3+}$-TPTZ complex to the ferrous form at low $\mathrm{pH}$. This reduction is monitored by measuring the absorption change at $593 \mathrm{~nm}$.

The reaction was carried out in a microtiter plate. $30 \mu \mathrm{L}$ of distilled water and $10 \mu \mathrm{L}$ properly diluted samples/standard were pipetted in a well of 96-well plate, then $200 \mu \mathrm{L}$ FRAP reagent (10 volumes of $250 \mathrm{mM}$ acetate buffer ( $\mathrm{pH}$ 3.6), one volume of $20 \mathrm{mM}$ ferric chloride solution and one volume of $10 \mathrm{mM}$ tripyridyl-s-triazin (TPTZ) in $40 \mathrm{mM} \mathrm{HCl}$ ) were added. The mixture was incubated at $37^{\circ} \mathrm{C}$ and the absorbance was taken after $8 \mathrm{~min}$ at $593 \mathrm{~nm}$.

The FRAP values was calculated and expressed as ascorbic acid equivalents per $100 \mathrm{~g}$ sample (fresh weight sour cherry/dried residue).

\subsection{2. $\mathrm{DPPH}$}

The DPPH free radical scavenging activity was measured using the method of Brand-Williams with modified as follows: $10 \mu \mathrm{L}$ of appropriately diluted sample or Trolox solution $(31.25,62.5,125$, $250,500,750$, and $1000 \mu \mathrm{M})$ and $50 \mu \mathrm{L}$ distilled water was added to $190 \mu \mathrm{L}$ of DPPH solution $(0.1 \mathrm{mM}$ in methanol) in a well of a 96-well plate. The mixture was shaken gently, incubated at $25^{\circ} \mathrm{C}$ and the 
absorbance was taken after $30 \mathrm{~min}$. The absorbance was measured at $517 \mathrm{~nm}$, using the microplate reader. DPPH was expressed as milligrams of trolox equivalents (mg TE/100 $\mathrm{g}$ fresh weight sour cherry/dried residue) $[26,60]$.

\subsubsection{TEAC}

Determination of Trolox Equivalent Antioxidant Capacity (TEAC). This assay was performed as reported previously with slight modification. ABTS radical cations were prepared by mixing equal volumes of ABTS $\left(7 \mathrm{mM}\right.$ in $\left.\mathrm{H}_{2} \mathrm{O}\right)$ and potassium persulfate $\left(4.9 \mathrm{mM}\right.$ in $\left.\mathrm{H}_{2} \mathrm{O}\right)$, and the solution was left to stand in the dark for 12-16 h at room temperature; then the above solution was filtered and diluted with $80 \%$ ethanol to an absorbance of about 2 at $734 \mathrm{~nm}$. $70 \mu \mathrm{L}$ of $80 \%$ ethanol and $10 \mu \mathrm{L}$ properly diluted samples/standard were pipetted in a well of 96-well plate, then $190 \mu \mathrm{L}$ ABTS solution in a well of a 96-well plate, and the absorbance was recorded at $734 \mathrm{~nm}$ after $30 \mathrm{~min}$ of incubation at room temperature. Trolox was used as standard, and a standard calibration curve was obtained for Trolox at concentrations of $15.65,31.25,62.5,125,250,500$, and $1000 \mu \mathrm{M}$. The TEAC of samples was calculated from the standard curve of Trolox and expressed as gram of Trolox equivalents (TE) per $100 \mathrm{~g}$ of fresh weight sour cherry/dried residue (g TE/100 g) [61].

\subsubsection{Photochemiluminescence Assay (PLC)}

This assay was described by Popov and Lewin, and distributed as a complete system under the name Photochem ${ }^{\circledR}$ by Analytik Jena AG (Jena, Germany).

In the PCL assay, the photochemical generation of $\left(\mathrm{O}_{2}{ }^{-}\right)$free radicals is combined with the sensitive detection by using chemiluminescence. The assay is initiated by optical excitation of photosensitizer (S), resulting in the generation of the superoxide radical anion.

$$
\mathrm{S}+\mathrm{hv}+\mathrm{O}_{2} \rightarrow\left[\mathrm{S}^{*} \mathrm{O}_{2}\right] \rightarrow \mathrm{S}^{\bullet+}+\mathrm{O}_{2}^{\bullet-}
$$

There are two different protocols: ACW (water-soluble antioxidant capacity) and ACL (lipid-soluble antioxidant capacity) so both of the hydrophilic and the lipophilic antioxidants can be measured separately. These are standardized conditions, so the results are comparable to other assays. The antioxidant potential was assayed by means of the lag phase (ACW) or by means of the area under the curve (ACL) at different concentrations [51,52].

\section{A. ACL}

The lipophilic antioxidants were measured with the ACL kit. The reaction solutions were prepared by mixing $2.3 \mathrm{~mL}$ Reagent 1 (methanol), $200 \mu \mathrm{L}$ Reagent 2 (buffer solution), $25 \mu \mathrm{L}$ Reagent 3 (photosensitizer and detection reagent), and 0-30 $\mu \mathrm{L}$ of Reagent 4 (calibration standard for quantification of lipophilic antioxidants in Trolox equivalents) or $10 \mu \mathrm{L}$ of sample (beverage diluted with Reagent 1) were mixed and measured. The detector measures the current proportion to the generated luminescence as a function of measurement time. The detector signal, monitored for $180 \mathrm{~s}$. Results are expressed as mg equivalents of trolox per $100 \mathrm{~g}$ fresh weight sour cherry/dried residue [52].

\section{B. ACW}

The hydrophilic antioxidants were measured with the ACW kit. The reaction solutions were prepared by mixing $1.5 \mathrm{~mL}$ of Reagent 1 (buffer solution $\mathrm{pH}$ 10.5), $1 \mathrm{~mL}$ of Reagent 2 (reaction buffer), $25 \mu \mathrm{L}$ Reagent 3 (photosensitizer and detection reagent) and 0-30 $\mu \mathrm{L}$ of Reagent 4 (calibration standard for quantification of water-soluble antioxidants in ascorbic acid equivalents) or $10 \mu \mathrm{L}$ of sample (beverage diluted with Reagent 1). The detector measures the current proportion to the generated luminescence as a function of measurement time. The detector signal, monitored for $250 \mathrm{~s}$, includes a lag phase in which no luminescence can be detected. When the antioxidants are exhausted, the amount of radicals in the sample increases until the detected signal reaches the maximum. The length of the 
lag phase increases in function of the amount of the antioxidants in the sample, and it is calculated by determining the first derivative and the maximum point of the detected curve. The interstion point of the slope of the straight line with the $x$-axis defines the lag time. Results are expressed as $\mathrm{mg}$ equivalents of ascorbic acid per $100 \mathrm{~g}$ fresh weight sour cherry/dried residue [51].

\subsection{UHPLC Analysis}

Measurements were carried out using CromasterUltraRs UHPLC, equipped with diode array detector, automatic sampler and Agillent OpenLAB software. The sample components were separated on a Phenomenex Kinetex column $(2.6 \mu$, XB.C18, 100A, $100 \times 4.6 \mathrm{~mm})$.

UHPLC running conditions consisted of the following linear gradient steps

0 min solvent A $15 \%$,

0-25 min solvent $\mathrm{A}$ to $30 \%$,

25-30 min solvent A to $40 \%$,

30-40 min solvent A to 50\%.

Solvent A: $\mathrm{MeOH}$; Solvent B: 3\% $\mathrm{HCOOH}$ (Formic acid) in water.

Flow rate was $0.7 \mathrm{~mL} \mathrm{~min}^{-1}$ and oven temperature was kept at $25^{\circ} \mathrm{C}$. The anthocyanin content was analyzed quantitatively by comparison with the corresponding authentic standards. UV-vis detection was used at $535 \mathrm{~nm}$ wavelength for anthocyanins and $340 \mathrm{~nm}$ for flavonoid and phenolic compounds. The appropriate amounts of sour cherry extracts were measured and dissolved in solvent A. Injection volume was $10 \mu \mathrm{L}$.

\subsection{UHPLC-MS Analysis}

The UHPLC system (Dionex Ultimate 3000RS) was coupled to a Thermo Q Exactive Orbitrap mass spectrometer (Thermo Fisher Scientific Inc., Waltham, USA) equipped with an electrospray ionization source (ESI). The HPLC separation was achieved on a Themo Accucore C18 column (100 $\mathrm{mm} \times 2.1 \mathrm{~mm}$ $\times 2.6 \mu \mathrm{m})$. Sampler and oven temperature were maintained at $25{ }^{\circ} \mathrm{C}$, flow rate was $200 \mu \mathrm{L} \mathrm{min}{ }^{-1}$. Eluent A was water containing $0.1 \%$ formic acid and eluent $\mathrm{B}$ was methanol containing $0.1 \%$ formic acid. The following gradient elution program was used: $0 \mathrm{~min}, 95 \% \mathrm{~A} ; 0-3 \mathrm{~min}, 95 \% \mathrm{~A} ; 3-43 \mathrm{~min}$, $\rightarrow 0 \%$ A; 43-61 $\mathrm{min}, 0 \% \mathrm{~A} ; 61-62 \mathrm{~min}, \rightarrow 95 \%$ A; 62-70 $\mathrm{min}, 95 \%$ A. $2 \mu \mathrm{L}$ of the samples were injected in every run. The $\mathrm{Q}$ Exactive hybrid quadrupole-orbitrap mass spectrometer was operated with the following parameters: capillary temperature $320^{\circ} \mathrm{C}$, spray voltage $4.0 \mathrm{kV}$ in positive and $3.8 \mathrm{kV}$ in negative ionization mode. The resolution was set to 35,000. The mass range scanned was $150-1500 \mathrm{~m} / \mathrm{z}$. The maximum injection time was $100 \mathrm{~ms}$. The resolution was set to 17,500 in the cases of MS2 scans. The collision energy was 35 NCE. Sheath gas and aux gas flow rates were 32 and 7 arb, respectively. Xcalibur 4.0 (Thermo Fisher Scientific Inc., Waltham, USA) software was used to collect and analyze data.

\subsection{Statistical Analysis}

Data were expressed as means \pm standard errors. Data were statistically analyzed using the SPSS statistical software, version 23. (SPSS Inc, Chicago, IL, USA). One-way analysis of variance (ANOVA) with Tukey's honestly sgnificant difference test (homogeneity of variances) and Games-Howell significant difference test (not equal variances) were used to compare means among groups. The level of significance was set at $p<0.05$.

\section{Conclusions}

It is known that different types of extractants can extract a variety of bioactive compounds. Accordingly, just one solvent is not sufficient to extract the total antioxidant compounds of foods, solvent combination is necessary, and the choice of suitable solvents is essential. As a result of our investigation, we found that the amounts and antioxidant properties of the dissolved compounds are not significantly different in case of solvent combination 1 and 2 . However, Solvent combination 2 
(methanol-acetone-water) can not be used in the food technology, only alcohol-water extraction is suitable.

The choice of the appropriate solvent is just the first step, the next is the determination of the exact antioxidant capacity. To do this you will need to find the most appropriate measurement method for the food type, because they contain different antioxidant compounds. FRAP method is good for the determination of water soluble, low molecular weight components. However, anthocyanins and associated flavonoids are only slightly soluble in water, so this method can not be measured these well. Although the solvent of DPPH and TEAC methods is ethanol, there are certain limitations that block measurement of the anthocyanins rich in sour cherry. For instance, because of the steric accessibility of DPPH• radical, the DPPH method can not adequately measure anthocyanin compounds [47], and in case of TEAC, the degree and position of hydroxylation and methoxylation in the B ring of anthocyanins, affects the stability and reactivity and thereby the antioxidant capacity [62]. However, the ACL and ACW methods are suitable to determine the antioxidant activity of various chemical components in SC.

Supplementary Materials: The following are available.

Author Contributions: J.R. conceived and designed the experiments. A.N., E.S., L.S., A.B., J.R.H., M.M.S., and Z.C. performed the experiments. P.B., Z.C., and J.R. analyzed the data. A.N. and J.R. wrote the paper. All authors read and approved the final manuscript.

Funding: This research received no external funding.

Acknowledgments: The work is supported by the GINOP-2.3.2-15-2016-00042 project. This project is co-financed by the European Union and the European Social Fund. Furthermore, the research was financed by the Higher Education Institutional Excellence Programme (20428-3/2018/FEKUTSTRAT) of the Ministry of Human Capacities in Hungary, within the framework of the 4 . thematic programme of the University of Debrecen.

Conflicts of Interest: The authors declare no conflict of interest.

Dedication: This study is dedicated to Professor Sándor Biró on the occasion of his 70th birthday, and we honor his undisputed merits in the field of the microbial genetics.

\section{References}

1. Olden, E.J.; Nybom, N. On the origin of the Prunus cerasus L. Hereditas 1968, 59, 327-345. [CrossRef]

2. Wang, H.; Nair, M.G.; Iezzoni, A.F.; Strasburg, G.M.; Booren, A.M.; Gray, J.I. Quantification and Characterization of Anthocyanins in Balaton Tart Cherries. J. Agric. Food Chem. 1997, 45, 2556-2560. [CrossRef]

3. Myhrstad, M.C.; Carlsen, H.; Nordstrom, O.; Blomhoff, R.; Moskaug, J.O. Flavonoids increase the cellular glutathione level by transactivation of the g-glutamylcysteine synthetase catalytical subunit promoter. Free Radic. Biol. Med. 2002, 32, 386-393. [CrossRef]

4. Moskaug, J.O.; Carlsen, H.; Myhrstad, M.C.W.; Blomhoff, R. Polyphenols and glutathione synthesis regulation. Am. J. Clin. Nutr. 2005, 81, 277-283. [CrossRef] [PubMed]

5. Gutierrez, R.M. Effect of the hexane extract of Piper auritum on insulin release from beta-cell and oxidative stress in streptozotocin-induced diabetic rat. Pharmacogn. Mag. 2012, 8, 308-313. [CrossRef] [PubMed]

6. Mane, C.; Loonis, M.; Juhel, C.; Dufour, C.; Malien-Aubert, C. Food grade lingonberry extract: Polyphenolic composition and in vivo protective effect against oxidative stress. J. Agric. Food Chem. 2011, 59, 3330-3339. [CrossRef] [PubMed]

7. Martin, M.A.; Fernández-Millán, E.; Ramos, S.; Bravo, L.; Goya, L. Cocoa flavonoid epicatechin protects pancreatic beta cell viability and function against oxidative stress. Mol. Nutr. Food Res. 2014, 58, 447-456. [CrossRef]

8. Youdim, K.A.; Martin, A.; Joseph, J.A. Incorporation of the elderberry anthocya- nins by EC increases protection against oxidative stress. Free Radic. Biol. Med. 2000, 29, 51-60. [CrossRef]

9. Ciz, M.; Denev, P.; Kratchanova, M.; Vasicek, O.; Ambrozova, G.; Lojek, A. Flavonoids Inhibit the Respiratory Burst of Neutrophils in Mammals. Oxid. Med. Cell. Longev. 2012, 2012, 181295. [CrossRef]

10. Cassidy, A.; O’Reilly, E.J.; Kay, C.; Sampson, L.; Franz, M.; Forman, J.P.; Curhan, G.; Rimm, E.B. Habitual intake of flavonoid subclasses and incident hypertension in adults. Am. J. Clin. Nutr. 2011, 93, 338-347. [CrossRef] 
11. Xu, J.W.; Ikeda, K.; Yamori, Y. Cyanidin-3-glucoside regulates phosphorylation of endothelial nitric oxide synthase. FEBS Lett. 2004, 574, 176-180. [CrossRef] [PubMed]

12. Watson, R.R.; Preedy, V.R.; Zibadi, S. Polyphenols in Human Health and Disease, 1st ed.; Academic Press: Oxford, UK, 2014; pp. 86-90. ISBN 978-0-12-398456-2. [CrossRef]

13. Guo, H.; Ling, W.; Wang, Q.; Liu, C.; Hu, Y.; Xia, M. Cyanidin 3-glucoside protects 3T3-L1 adipocytes against $\mathrm{H}_{2} \mathrm{O}_{2}$ - or TNF- $\alpha$-induced insulin resistance by inhibiting c-Jun NH2-terminal kinase activation. Biochem. Pharmacol. 2008, 75, 1393-1401. [CrossRef] [PubMed]

14. Tang, Y.; Zhang, B.; Li, X.; Chen, P.X.; Zhang, H.; Liu, R.; Tsao, R. Bound Phenolics of Quinoa Seeds Released by Acid, Alkaline, and Enzymatic Treatments and Their Antioxidant and $\alpha$-Glucosidase and Pancreatic Lipase Inhibitory Effects. J. Agric. Food Chem. 2016, 64, 1712-1719. [CrossRef] [PubMed]

15. Shahidi, F.; Yeo, J.D. Insoluble-Bound Phenolics in Food. Molecules 2016, 21, 1216. [CrossRef] [PubMed]

16. Pérez-Jiménez, J.; Arranz, S.; Tabernero, M.; Díaz-Rubio, M.E.; Serrano, J.; Goñi, I.; Saura-Calixto, F. Updated methodology to determine antioxidant capacity in plant foods, oils and beverages: Extraction, measurement and expression of results. Food Res. Int. 2008, 41, 274-285. [CrossRef]

17. Andreasen, M.F.; Kroon, P.A.; Williamson, G.; Garcia-Conesa, M.T. Esterase Activity Able to Hydrolyze Dietary Antioxidant Hydroxycinnamates Is Distributed along the Intestine of Mammals. J. Agric. Food Chem. 2001, 49, 5679-5684. [CrossRef] [PubMed]

18. Pérez-Jiménez, J.; Díaz-Rubio, M.E.; Saura-Calixto, F. Non-extractable polyphenols, a major dietary antioxidant: Occurrence, metabolic fate and health effects. Nutr. Res. Rev. 2013, 26, 118-129. [CrossRef]

19. Pérez-Jiménez, J.; Saura-Calixto, F. Macromolecular antioxidants or non-extractable polyphenols in fruit and vegetables: Intake in four European countries. Food Res. Int. 2015, 74, 315-323. [CrossRef]

20. Kristl, J.; Slekovec, M.; Tojnko, S.; Unuk, T. Extractable antioxidants and non-extractable phenolics in the total antioxidant activity of selected plum cultivars (Prunus domestica L.): Evolution during on-tree ripening. Food Chem. 2011, 125, 29-34. [CrossRef]

21. Gómez-García, R.; Martínez-Ávila, G.C.G.; Aguilar, C.N. Enzyme-assisted extraction of antioxidative phenolics from grape (Vitis vinifera L.) residues. 3 Biotech 2012, 2, 297-300. [CrossRef]

22. Guo, L. Enzymatic hydrolysis of lotus rhizome starch using alpha-amylase and glucoamylase. J. Food Nutr. Res. 2017, 56, 372-380.

23. Anokwuru, C.; Sigidi, M.; Boukandou, M.; Tshisikhawe, P.; Traore, A.; Potgieter, N. Antioxidant Activity and Spectroscopic Characteristics of Extractable and Non-Extractable Phenolics from Terminalia sericea Burch. ex DC. Molecules 2018, 23, 1303. [CrossRef] [PubMed]

24. Wang, H.; Cao, G. Oxygen radicals absorbing capacity of anthocyanins. J. Agric. Food Chem. 1997, 45, $304-309$. [CrossRef]

25. Frankel, E.N.; Meyer, A.S. The problems of using one-dimensional methods to evaluate multifunctional food and biological antioxidants. J. Sci. Agric. 2000, 80, 1925-1941. [CrossRef]

26. Brand-Williams, W.; Cuvelier, M.E.; Berset, C. Use of a free radical method to evaluate antioxidant activity. Food Sci. Technol. 1995, 28, 25-30. [CrossRef]

27. Sanchez-Moreno, C.; Larrauri, J.A.; Saura-Calixto, F. A procedure to measure the antiradical efficiency of polyphenols. J. Sci. Food Agric. 1998, 76, 270-276. [CrossRef]

28. Saura-Calixto, F.; Goñi, I. Antioxidant capacity of the Spanish Mediterranean diet. Food Chem. 2006, 94, 442-447. [CrossRef]

29. Homoki, J.R.; Nemes, A.; Fazekas, E.; Gyémánt, G.; Balogh, P.; Gál, F.; Al-Asri, J.; Mortier, J.; Wolber, G.; Babinszky, L.; et al. Anthocyanin composition, antioxidant efficiency, and a-amylase inhibitor activity of different Hungarian sour cherry varieties (Prunus cerasus L.). Food Chem. 2016, 194, 222-229. [CrossRef] [PubMed]

30. Chaovanalikit, A.; Wrolstad, R.E. Anthocyanin and polyphenolic composition of fresh and processed cherries. J. Food Sci. 2004, 69, 73-83. [CrossRef]

31. Levaj, B.; Dragović-Uzelac, V.; Delonga, K.; Ganić, K.K.; Banović, M.; Kovačević, D.B. Polyphenols and volatiles in fruits of two sour cherry cultivars, some berry fruits and their jams. Food Technol. Biotechnol. 2010, $48,538-547$.

32. Han, J.H.; Lee, H.J.; Cho, M.R.; Chang, N.; Kim, Y.; Oh, S.Y.; Kang, M.H. Total antioxidant capacity of the Korean diet. Nutr. Res. Pract. 2014, 8, 183-191. [CrossRef] [PubMed] 
33. Bonerz, D.; Würth, K.; Dietrich, H.; Will, F. Analytical characterization and the impact of ageing on anthocyanin composition and degradation in juices from five sour cherry cultivars. Eur. Food Res. Technol. 2007, 224, 355-364. [CrossRef]

34. Wojdyło, A.; Nowicka, P.; Laskowski, P.; Oszmiański, J. Evaluation of sour cherry (Prunus cerasus L.) fruits for their polyphenol content, antioxidant properties, and nutritional components. J. Agric. Food Chem. 2014, 51, 12332-12345. [CrossRef] [PubMed]

35. Jakobek, L.; Seruga, M.; Seruga, B.; Novak, I.; Medvicovic-Kosanovic, M. Phenolic compound composition and antioxidant activity of fruits of Rubus and Prunus species from Croatia. Int. J. Food Sci. Technol. 2009, 44, 860-868. [CrossRef]

36. Toydemir, G.; Capanoglu, E.; Gomez-Roldan, M.V.; de Vos, R.C.H.; Boyacioglu, D.; Hall, R.D.; Beekwilder, M.J. Industrial processing effects on phenolic compounds in sour cherry (Prunus cerasus L.) fruit. Food Res. Int. 2013, 53, 218-225. [CrossRef]

37. Arteel, G.E.; Sies, H. Protection against peroxinitrite by cocoa polyphenol oligomers. FEBS Lett. 1999, 462, 167-170. [CrossRef]

38. Lunder, T.L. Catechins of green tea: Antioxidant activity. In Phenolic Compounds in Food and Their Effects on Health II, 1st ed.; Huang, M.T., Ho, C.T., Lee, C.Y., Eds.; American Chemical Society Inc.: Washington, DC, USA, 1992; Volume 507, pp. 114-120. ISBN 9780841224766.

39. Pannala, A.S.; Chan, T.S.; O’Brien, P.J.; Rice-Evans, C.A. Flavonoid B-ring chemistry and antioxidant activity: Fast reaction kinetics. Biochem. Biophys. Res. Commun. 2001, 282, 1161-1168. [CrossRef]

40. Rice-Evans, C.A.; Packer, L. Flavonoids in Health and Disease; Dekker: New York, NY, USA, 1997.

41. Gonzales-Manzano, S.; Santos-Buelga, C.; Perez-Alonso, J.J.; Rivas-Gonzalo, J.C.; Escribano-Bailon, M.T. Characterization of the mean degree of polymerization of proanthocyanidins in red wines using Liquid Chromatography-Mass Spectrometry (LC-MS). J. Agric. Food Chem. 2006, 54, 4326-4332. [CrossRef]

42. Hagerman, A.E.; Riedl, K.M.; Jones, G.A.; Sovik, K.N.; Ritchard, N.T.; Hartzfeld, P.W.; Riechel, T.L. High molecular weight plant polyphenolics (tannins) as biological antioxidants. J. Agric. Food Chem. 1998, 46, 1887-1892. [CrossRef]

43. Shi, J.; Yu, J.; Pohorly, J.E.; Kakuda, Y. Polyphenolics in grape seeds-biochemistry and functionality. J. Med. Food 2003, 6, 291-299. [CrossRef]

44. Khanal, R.C.; Howard, L.R.; Prior, R.L. Procyanidin content of grape seed and pomace, and total anthocyanin content of grape pomace as affected by extrusion processing. J. Food Sci. 2009, 74, 174-182. [CrossRef] [PubMed]

45. Manach, C.; Williamson, G.; Morand, C.; Scalbert, A.; Remesy, C. Bioavailability and bioefficacy of polyphenols in humans. I. Review of 97 bioavailability studies. Am. J. Clin. Nutr. 2005, 81, 230-242. [CrossRef] [PubMed]

46. Capanoglu, E.; Boyacioglu, D.; de Vos, R.C.H.; Hall, R.D.; Beekwilder, J. Procyanidins in fruit from Sour cherry (Prunus cerasus) differ strongly in chainlength from those in Laurel cherry (Prunus lauracerasus) and Cornelian cherry (Cornus mas). J. Berry Res. 2011, 1, 137-146. [CrossRef]

47. Boligon, A.A.; Machado, M.M.; Athayde, M.L. Technical evaluation of antioxidant activity. Med. Chem. 2014, 4, 517-522. [CrossRef]

48. Prior, R.L.; Cao, G. Analysis of botanicals and dietary supplements for antioxidant capacity: A review. J. AOAC Int. 2000, 83, 950-955. [PubMed]

49. Huang, D.; Ou, B.; Prior, R.L. The chemistry behind antioxidants capacity assays. J. Agric. Food Chem. 2005, 53, 1841-1856. [CrossRef] [PubMed]

50. Litwinienko, G.; Ingold, K.U. Abnormal solvent effects on hydrogen atom abstractions. 1. The reactions of phenols with 2,2-diphenyl-1-picrylhydrazyl (dpph•) in alcohols. J. Org. Chem. 2003, 68, 3433-3438. [CrossRef] [PubMed]

51. Popov, I.N.; Lewin, G. Photochemiluminescent detection of antiradical activity. 2. Testing nonenzymic water-soluble antioxidants. Free Radic. Biol. Med. 1994, 17, 267-271. [CrossRef]

52. Popov, I.N.; Lewin, G. Photochemiluminescent detection of antiradical activity; IV: Testing of lipid-soluble antioxidants. J. Biochem. Biophys. Methods 1996, 31, 1-8. [CrossRef]

53. Kim, D.; Heo, H.J.; Yang, H.S.; Lee, C.Y. Sweet and sour cherry phenolics and their protective effects on neuronal cells. J. Agric. Food Chem. 2005, 53, 9921-9927. [CrossRef] 
54. Hartzfeld, P.W.; Forkner, R.; Hunter, D.M.; Hagerman, A.E. Determination of hydrolysable tannins (gallotannins and ellagitannins) after reaction with potassium iodate. J. Agric. Food Chem. 2002, 50, 1785-1790. [CrossRef] [PubMed]

55. Porter, L.; Hrstich, L.; Chan, B. The conversion of procyanidins and prodelphinidins to cyaniding and delphinidin. Phytochemistry 1985, 25, 223-230. [CrossRef]

56. Reed, J.; McDowell, R.E.; Van Soest, P.J.; Horvarth, P.J. Condensed tannins: A factor limiting the use of cassava forage. J. Sci. Food Agric. 1982, 33, 213-220. [CrossRef]

57. Singleton, V.L.; Orthofer, R.; Lamuela-Raventós, R.M. Analysis of total phenols and other oxidation substrates and antioxidants by means of folin-ciocalteu reagent. Methods Enzymol. 1999, 299, 152-178. [CrossRef]

58. Prior, R.L.; Fan, E.; Ji, H.; Howell, A.; Nio, C.; Payne, M.J.; Reed, J. Multi-laboratory validation of a standard method for quantifying proanthocyanidins in cranberry powders. J. Sci. Food Agric. 2010, 90, 1473-1478. [CrossRef] [PubMed]

59. Benzie, I.F.; Strain, J.J. The ferric reducing ability of plasma (FRAP) as a measure of "antioxidant power": The FRAP assay. Anal. Biochem. 1996, 239, 70-76. [CrossRef] [PubMed]

60. Blois, M.S. Antioxidant determinations by the use of a stable free radical. Nature 1958, 181, 1199-1200. [CrossRef]

61. Miller, N.J.; Rice-Evans, C.A.; Davies, M.J.; Gopinathan, V.; Milner, A. A novel method for measuring antioxidant capacity and its application to monitoring the antioxidant status in premature neonates. Clin. Sci. 1993, 84, 407-412. [CrossRef]

62. Montoro, P.; Tuberoso, C.I.; Piacente, S.; Perrone, A.; De Feo, V.; Cabras, P.; Pizza, C. Stability and antioxidant activity of polyphenols in extracts of Myrtus communis L. berries used for the preparation of myrtle liqueur. J. Pharm. Biomed. Anal. 2006, 41, 1614-1619. [CrossRef]

Sample Availability: Samples of the compounds are not available from the authors.

(C) 2018 by the authors. Licensee MDPI, Basel, Switzerland. This article is an open access article distributed under the terms and conditions of the Creative Commons Attribution (CC BY) license (http://creativecommons.org/licenses/by/4.0/). 